

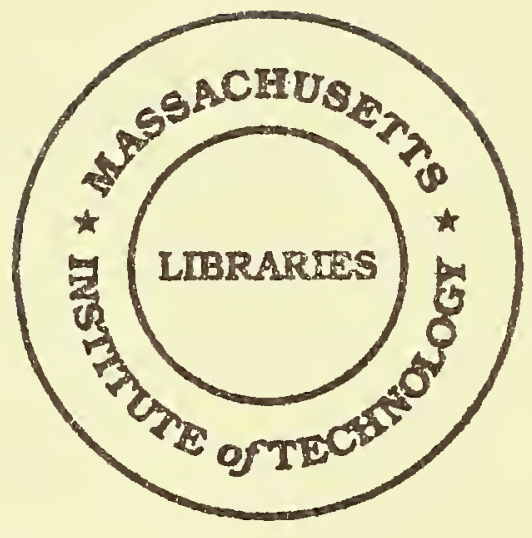





\section{Digitized by the Internet Archive in 2011 with funding from}

Boston Library Consortium Member Libraries 


\section{working paper} department of economics

Reputation Effects and the Limits of Contracting: A Study of the Indian Software Industry

Abhijit Banerjee Esther Duflo

No. 99-14

July 1999

\section{massachusetts} institute of technology

50 memorial drive cambridge, mass. 02139 


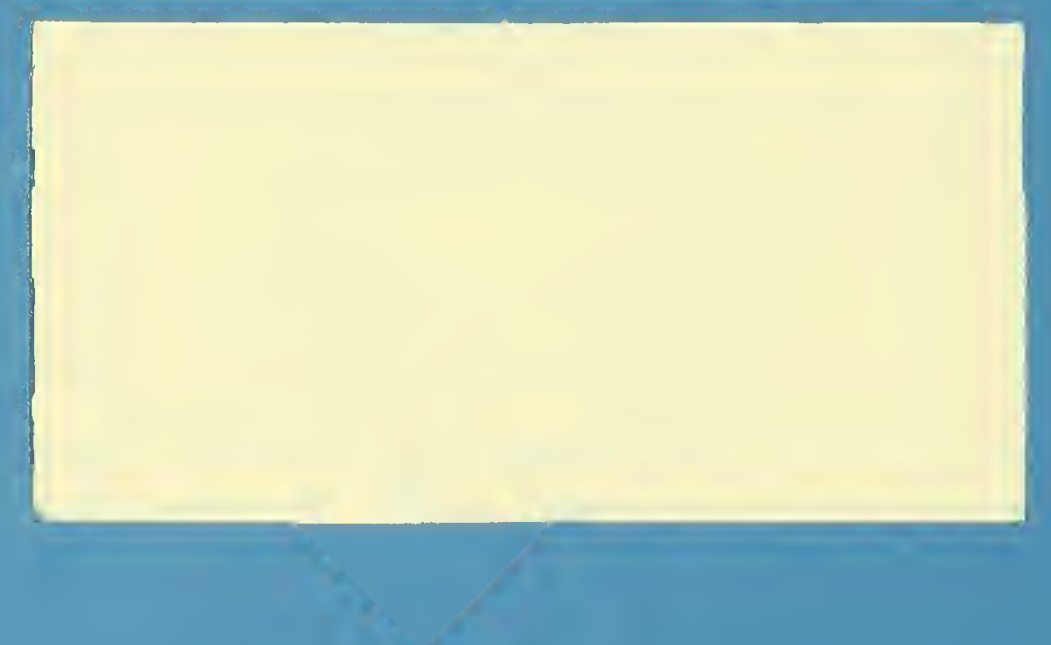




\section{WORKING PAPER \\ DEPARTMENT \\ OF ECONOMICS}

Reputation Effects and the Limits of Contracting:

A Study of the Indian Software Industry

Abhijit Banerjee

Esther Duflo

No. 99-14

July 1999

MASSACHUSETTS

INSTITUTE OF

TECHNOLOGY

50 MEMORIAL DRIVE

CAMBRIDGE, MASS. 02142 


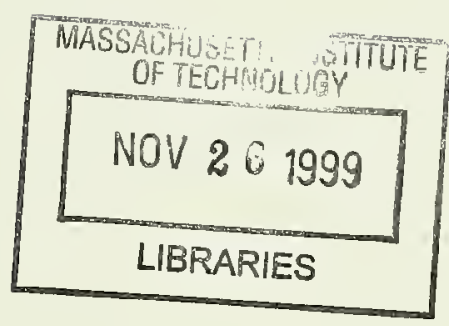




\title{
Reputation Effects and the Limits of Contracting: A Study of the Indian Software Industry
}

\author{
Abhijit V. Banerjee* and Esther Duflo ${ }^{\dagger}$ \\ First Draft: November, 1998 - This version June 11, 1999
}

\begin{abstract}
This paper examines evidence of the rolc that reputation plays in determining contractual outcomes. We conduct an empirical analysis of the Indian customized software industry: Wc analyzc a data set containing detailed information about 230 projects carricd out by 125 software firms that we had previously collected. The evidence supports the vicw that reputation matters. Ex ante contracts as well as the outcome after ex-post renegotiation vary with firms' charactcristics plausibly associated with reputation. We argue that this pattern is not consistent with optimal risk sharing and propose a model of the industry where reputation determincs contractual outcomes, whose predictions are consistent with scveral facts obscrved in the data. We arguc that there is no obvious alternative cxplanation to the patterns present in the data.
\end{abstract}

- Massachusctts Institutc of Technology. Email: bancrjec@mit.cdu

${ }^{\dagger}$ Massachusctts Institutc of Technology. Email: cduflo@mit.cdu

${ }^{\ddagger}$ We thank Daron Accmoglu, Philippe Aghion, Roland Bcnabou, Mathias Dewatripont, David Gencsove, Jonathan Guryan, Oliver Hart, Doug Miller, Dilip Mookherjcc, Ashok Rai, Emmanucl Sacz, Andrci Shleifer, Jcan Tirolc, and Richard Zeckhauser for helpful conversations and Paul Joskow for encouragement and support. We acknowledge financial support from the the National Science Foundation, Alfred P. Sloan Foundation, the Sluultz Fund and the John D. and Catherine MacArthur Foundation. Wc are especially grateful to the software professionals in India, who patiently answercd our many questions, and in particular to Mr N. R. Narayana Murthy, from Infosys Technologics Limitcd, whose help and insights were crucial throughout this project. 



\section{Introduction}

The idea that there are severe limits to what can be achicved through contracting has had an cnormous impact on the way cconomists now think about firms, markets and governments. Correspondingly, there has bcen a growing cmphasis on the role of reputation as a way of counteracting the problems created by the limitations of contracting. ' Whilc less often cmphasized, a vicw of the world which gives central importance to issucs of contracting, reputation and trust, also has important consequences for the process of growth and devclopment. Most importantly, it suggests that the lack of a proper infrastructure for contract enforcement (which

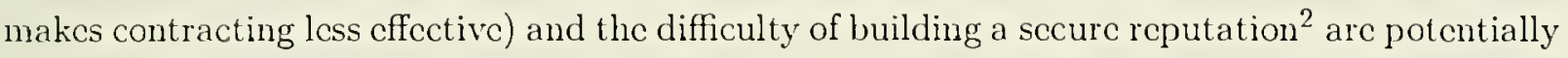
important determinants of success in getting out of poverty, along with the morc conventional detcrminants such as human capital and physical infrastructurc.

This paper attempts to quantitatively asscss the importance of reputation and, by implication, the scriousness of the limits on contracting in the context of the Indian customized softwarc industry. Customized softwarc is an obrious place to study such effects since the desired cnd-product tends to be extremely complex and difficult to describe ahead of time in a way that a third party (such as a court) would understand. In fact, typically the partics to the contract themsclves do not fully understand what they want until well into the production process. Therefore, it scems naive to cxpect that they could writc a contract enforccable by the courts that would fully cover all contingencics that could arisc in the production process. Morcover, softwarc production docs not require very much fixcd capital: indecd most firms nowadays simply own a number of PCs (which arc chcap and getting chcapcr). The rest, including the premiscs, access to a mainframe and links to a satcllitc, can all be rented. ${ }^{3}$ This limits the possibility of the reputation effects that interest us being confounded with the effects of deferential access to capital or the lack of rcal compctition.

The Indian software industry is suitable for such a study for a number of reasons: First, it is an industry which is quitc large (cmploying 140,000 pcople with a turnover of $\$ 1.75$ billion in

\footnotetext{
${ }^{1}$ Scc for cxamplc Grcif (1994), Bakcr, Gibbons and Murphy (1997).

"Stcmming from prejudicc, or a history of bad pcrformance, as cmphasized by Tirolc (1996).

${ }^{3}$ In India, the government has actually invested heavily, and by all accounts fruitfully, to make sure that firms have the option of renting expensive fixed inputs (such as cxpensive computers, building space and cquipment for satcllitc telccommunication) in virtual "Softwarc Techonology Parks" (STPI, 1997).
} 
1997-98) and growing fast (at an avcragc annual growth rate of $54 \%$ over the past six years). Sccond, its main focus is on cxports (more than $60 \%$ of its revenue comes from cxports) and a large (over 30\%) and fast-growing share of the cxports is customized software. Morcover, the industry's current focus is on cxpanding the cxport of customized software relative to its other businesses on the grounds that this is likely to be its best bet for the near future (NASSCOM, 1997). Conscquently, the limits of contracting are a major issue in this industry and one that cveryone is clcarly concerned about. Finally, the fact that the contracts are typically across long distances makes contracting more complicated both by making monitoring somewhat harder and, perhaps more importantly, because of the inherent difficultics of international litigation (combined with the deficiencies of the Indian court system). The data we use in this paper comes from intervicws of 125 software companics in three major software development centers in India (Bangalore, Hyderabad and Punc) ${ }^{5}$. We collected detailed data on the company and on the two last projects they have completed, including what kinds of contracts were initially arranged between them and how the contract got rencgotiated as the project cvolved (we have a total of 236 contracts in our data set).

Prima facic, the data supports both the vicw that contracting is very limited and the vicw that reputation is important. All contracts in our sample are cither fixed-pricc contracts or time and matcrial contracts. In fixed-price contracts the software firm - henceforth, the firm gets a fixed price and is supposed to pay for all realized costs. In time and material contracts the software buycr - henceforth, the clicnt - is supposcd to pay for all realized costs. A large fraction of the contracts do however get renegotiated ex post: the buyer does not pay the entire cost in almost half the fixed contracts and the clicnt pays less than the full amount in about a quarter of the time and matcrial contracts. There is also a simple pattern in both the kind of contract that gets chosen and the sharing of the costs which is a result of the renegotiation. It is shown in Figures 1 and 2. Figure 1 shows the fraction of fixcd-price projects as a function

\footnotetext{
${ }^{4}$ In the past, cxport of softwarc scrvices was almost cxclusively on-sitc scrvices (or "body-shopping"), cf. Hecks (1996).

"In each city, we interviewed half of the firms who belong to the software technology park (all cxporters do). We sclected the firms randomly, but we oversampled the firms that are not fully-owned subsidiarics. No firm refused to mect with us and answer the questionnairc. Some appointments could not be arranged duc to the CEO's unavailability at the moment we were interviewing, and these firms were replaced.
} 
of the foundation date of the software firm, and Figure 2 shows the share of overrun ${ }^{6}$ paid for by the firm as a function of the age of the software firm. ${ }^{7}$ Both are sharply increasing with the starting date of the firm. In particular, firms created in 1994 or after (half of the sample) bear a substantially larger share of the overrum than older firms on average, and the sharc of overrun they bear is increasing more sharply with age over this range. Measured both in terms of the ex ante contract and in terms of ex post outcome, young firms bear a larger share of the 'risk' of cach software project.

This cffect of age is perhaps the main cmpirical finding of the paper. We interpret this as an effect of reputation on the grounds that the firms that started in the industry a long time ago and have survived are more likely to be the kinds of firms that clients can trust - the older firms that cannot be trusted arc likely to have already gonc out of business (since cventually people would have got to know about them).

To provide further support for our interpretation of the age effect as a reputation effect, in Section 5 we show that a similar pattern exists when we use other potential measures of reputation such as whether there has becn a previous transaction between the firm and the client, whether it is an internal project (i.c., with a client who either owns the firm or has a longterm arrangement with the firm) ${ }^{8}$, ctc. Further, we show that different kinds of reputation are to some cxtent substitutes. For cxample, the difference between young and old firms disappears among firms that work for an internal clicnt.

In scctions 3 and 4 of the paper we develop a simple model bascd on our observation of the industry which explains why reputation would have the observed cffect on contractual outcomes. The basic idea of the model is that in most cases by the end of the project the firm and the client know who was responsible for cost overruns. Whilc this is not contractible, firms and clients could nevertheless benefit from it if they could commit to always follow a certain norm. The norm wc cmphasizc here - clcarly there can be other norms that will also work - is that of being rcliablc: reliable firms always try very hard to cnsure that they do not exceed the cost overrun that they had implicitly promiscd, and pay for any extra overrun when they fail to do so. The problem is that this is typically not consistent with short-run profit maximization by the firm or

\footnotetext{
"The amount of the project cost that gocs beyond the initial prediction.

'Bccausc the number of firms per year in the sample is small for firms crcatcd bcforc 1988, we have groupcd all these firms together.

${ }^{*}$ We will describe this type of structurc below.
} 
the clicnt, and can only be sustained if the firms and clients are cither innately reliable or, more conventionally, if the particular cquilibrium that they are playing induces them to put some valuc on their reputation. We look at cquilibria where a ccrtain fraction of firms and clicnts are reliable and the rest are not and investigate the implications of a change in the fraction of those who are reliable (interpretcd as a change in the average reputation of the firms). The basic trade-off that governs what happens is that fixcd-price contracts are best for protecting reliable buycrs from unreliable scllers while the reverse is true of time and matcrial contracts. Therefore there should be more fixcd-price contracts if the share of buycrs who are likely to be reliable is smaller; which is consistent with the cvidence we describe above. We also arguc that a number of other predictions from this model arc consistcnt with what we obscrve.

While we do provide some cvidence supporting the broad premiscs of our model, it is clcar that we cannot provide sharp cnough cvidence to rulc out altcrnative reputation models: it is possible, for cxample, that the relevant reputation is for honesty or for a different form of reliability. The objective of this paper is not to distinguish among different kinds of reputation. Howcver our reputation-bascd story docs rulc out many altcrnative cxplanations. In particular it rulcs out models where there are no agency problems as well as models of agcney problems where there is no learning about the firm's typc.

Of coursc, this is all conditional on cstablishing that we are in fact correctly interpreting the data when we impose the reputation model on it. In other words, it still remains possible that what we are picking up here is the effect of some other variable which happens to be correlated with these measures of reputation. In Scction 6, we consider some of thesc cxplanations. They fall broadly in two classes.

First, there is a class of altcrnative cxplanations which rulc out agcncy problems: the differences in the contracts is then explained either by differences in risk-sharing or by differences in the production technology available to the firm. Against this view, we first argue that it is very implausible that the contractual variations that we obscrve arc a result of optimal risk-sharing. The basic point is that in our data sct, firms are usually much smaller than their clients and young firms are especially small. It is thereforc very hard to understand why firms bear so much of the risk ( $57 \%$ on averagc) and why cspccially the smallest and youngest firms bcar the most. ${ }^{9}$ In response to the view that there are differences in the production technology (essentially that

\footnotetext{
${ }^{9}$ There are of course other determinants of the sharing of the risk. We discuss these issues in section 6 .
} 
young firms are more incompetent) we point out that the natural effect of such incompetence should be to lower the price the young firms gets paid rather than to make them bear a lot of risk that they can ill afford. Morcorer the cvidence docs not support the vicw that the differences in competence between the firms is of a magnitude that can cxplain the differences in the contracts. For cxample, we present in Figure 3 the average overrun as a function of firm's foundation datc. If the high shares of orcrrun paid by young firms werc a way to make them pay for higher ovcrrun, wc should sce avcragc ovcrrun falling with agc. If anything, the oppositc sccms to be truc.

The sccond class of competing thcorics posits that there arc agcncy problcms but no lcarning about the firm: we point out that this conflicts with the cvidence on the effects of sources of reputation other than age. These and related issues are discussed at some length in Scetion 6.

As a final picce of cvidence, we cmphasizc the fact that the nccessity to build reputation and trust is recognized and is cmphasized repcatedly at the industry level as well as by individual firms. For cxample, the National Association of Softwarc Services Companics (NASSCOM) directory of the Indian Software industry has a large section on "quality" (NASSCOM, 1997). The main clement they stress is the number of Indian firms that have ISO 9000 certification or are in the process of acquiring it (ISO-certificd firms have proren that their softwarc development processes follow approved routines, which is a way for firms to cstablish a reputation). The association provides technical consulting to any member who wants to get ISO certification. The Indian gorernment provides financial incentives for firms who acquirc it. At the individual lcvel, cfforts to develop a rcputation arc also obvious. ${ }^{10}$

This paper is a part of a small but growing number of papers that study the cmpirics of contractual choicc. ${ }^{11}$ Among recent papers Crocker and Rcynolds (1993) is most closcly relatcd to this work. They examinc the detcrminants of the choice between fixed-price contracts and more flexible contracts in U.S. Air Force engine procurcment. In their vicw, the kcy trade-off is the following: fixcd-price contracts protect the government against ex post opportunism (in particular it makes it usclcss for the contractors to claim higher costs) but they require the

\footnotetext{
1" $20 \%$ of the firms in our sample already have ISO certification. $13 \%$ are in the process of getting it.

"Montererde and Tecce (1982), Masten and Crocker (1985), Joskow (1987) and Pittman (1991) are important carly papers on this subject. These papers differ from ours in studying settings where there arc huge relationshipspecific investincnts and very long term relationships are the norm and where the kcy trade-off is between tightness of contract (or control) and flexibility.
} 
ability to draft an exhaustive list of requirements (a complete contract), which is possible, but costly. Time and matcrial contracts do not require a truly complete agrecment ex ante, but open the room for opportunistic behavior by the contractor. ${ }^{12}$ Contracts will tend to be fixed-price if the nature of the engine makes them casy to draft (if the engine is well known or the production cycle is short), and if the contractor is morc likcly to bchave opportunistically. Their cmpirical analysis of a pancl of 44 contracts between the government and two contractors confirms these predictions. Their work shares thereforc a central intuition with ours: the reputation of the contractor docs matter for the choice of contracts. ${ }^{13}$ The more reputed a firm is, the less likely it is that the contract will be fixed-price. The central difference is that fixed-price contracts are not associated with any ex post cost for the contractor, since fixed-price contracts are "truly complete agrcements". In contrast, we recognize the fact that in the software industry the contract is never complete. Fixed-price contracts necd not be more preciscly drafted than time and material contracts. Overrun happens in both types of contracts. The central trade-off is between containing opportunism by the clicnt and opportunism by the firm.

Lafontainc and Shaw (1996) is another paper that looks at the effect of a firm's age on contracts (in the context of franchising) and finds that the franchiscr's age has no cffect on the contract. However as they point out, by changing the franchisc contract over time a franchiscr runs the risk of hurting its early franchisecs (who are locked into one contract while their compctitors get a different contract that perhaps allows them to be more aggressive). Bccause of this cross-contract cxtcrnality, contracts may not change very much over time, cven if the market over time becomes more knowledgeable about the franchiscr. ${ }^{14}$

The rest of the paper is organized as follows: In Section 2, we describe the institutional

\footnotetext{
${ }^{12}$ Bajari and Tadelis (1999) cmphasize a related trade-off in the private sector building industry (in a model where there are no unobserved difference among contractors). Time and material contracts give the contractor little incentive to control the costs, but do not require complete drafts. Fixed price contracts give the contractor strong incentives to control cost, but require more precisc design to avoid costly bargainig if changes are necded during the completion of the project. The time scale and the complexity of the project will determine which contract is chosen.

${ }^{13}$ In their paper, they measure the reputation by the number of litigation conflicts that the contractors had in the past.

${ }^{14}$ This paper is also related to papers such as Barron and Umbeck (1984), Shcpard (1993) and Genesove (1993) which test the implications of theories based on aymmetric information in industrial contcxts (but not the implications for the choice of the contract).
} 
settings in more detail and present a number of basic facts about the production of customized softwarc. The model is presented in Scction 3 and its predictions about how reputation shapes the contractual forms as well as the ex post outcome are described in Section 4. In Section 5, we provide cvidence which, in our vicw, clcarly supports the implications of this model. In Section 6, we discuss alternative explanations of the pattern observed in the data. Section 7 concludes.

\section{Institutions and Basic Facts}

We begin by describing the scquence of cvents leading to the off-shorc production of a picce of softwarc. $^{15}$ The project begins when the client sends a request for proposal to onc or more firms. Each interested firm studics the request (this costs the firm $1.25 \%$ of the total project cost for the incdian cxtcrnal project ${ }^{16}$ ), and submits a proposal, which includes, among other things, a proposed mode of payment and an estimate of how much the clicnt would have to pay. The clicnt chooses a firm, and the firm and the client agrec on a contract. The contract specifies an estimate of effort necded to complete the project, a mode of payment, financial details (price, etc.) and a projected schedule for deliverables (which are specific milestones - corresponding to phases of the software development process or to modules of the software - that will be reached in the course of completing the project). The work then starts. The first phase is the writing of specifications. The firm, in collaboration with the user at the client's end, writes the set of functions that the software will cxccutc. For the median project, it takes $10 \%$ of the total project effort to complete this phasc. ${ }^{17}$ At the end of this part of the project, what the clicnt wants and what it would cost is usually clcarer to both the clicnt and the firm and the schedule of deliverables is sometimes amended or clarificd.

The sccond phase of the work is the lower lcvel design, coding and testing of the software. When a specificd milestone is reached, the firm sends the deliverable to the clicnt. Each time this happens the clicnt can either acknowledge that it has becn delivered (by signing off) or request changes. The firms also send regular status reports to the clients (a little less than once

\footnotetext{
is Table 1 shows the descriptive statistics mentioned in this paragraph.

If Those projects where the clicnt docs not own the firm or docs not effectively control the part of the firm which is working towards tlie completion of the project (sce below).

${ }^{17}$ For some projects, specifications writing and subsequent work are decoupled. One firm - or the clicnt itsclf - writes the spccifications, and another firm completes the project.
} 
a weck on average), kecping the clicnts up-to-date about the progress of the project.

In terms of project outcomes our main focus will be on ovcrrun: overrun in industry parlance is the difference between the amount of effort actually necded to complete the project and the cstimated cffort given in the contract. It is therefore important to be clear about what firms mean by an estimatc. A standard textbook on software management (Pressman (1997), has an cntire chapter on estimation. He describes the process as follows:

'The project planner begins with a bounded statement of software scope and from this statcment attempts to decompose softwarc into problem functions that can cach be cstimated individually. Linc of Code or function points (the cstimation variable) is then estimated for each function. Alternatively, the planner may choose another component for sizing, such as classes or objects, changes or business processes impacted. Bascline productivity metrics (i.c., line of code per person-month or function point per person months) are then applied to the appropriate estimation variable and cost or effort for the function is derived. Function estimates are combined to produce an overall cstimate for the cntirc project.' (Pressman (1997))

Our interpretation of this and other matcrial in this book (which is also consistcnt with what we have lcarned from industry sources) is that the estimate is the firm's best guess about how much cffort will be needed to complete the project, assuming that the firm's current understanding of the project is correct and that the firm adheres to its own productivity norms. ${ }^{18}$ The estimate is thercforc clearly not meant to be an unbiased estimatc of how much effort the project will actually takc. This is important because it tells us that overrun represents the cxtent of deviation from the firm's initial plan of action.

This also tells us that overruns ought to be quite common: first, because the needs of the clicnt are typically not very clcar at the very beginning of a rclationship - cven to the clicnt himsclf. Morcover the clicnt may not put cnough cffort into understanding and cxplaining what he wants. Not surprisingly then, the firm often does not understand what the client really wants. When, in the course of the project, the necds of the client cventually become clear, changes have to be made and these are costly. Sccond, the amount of time and effort necded to design and

\footnotetext{
INIn other words, the presumption behind the estimate is that the firm has understood perfectly what the clicnt wants and that the firm implements the project at its normal level of productivity.
} 
code a picce of softwarc is difficult to cvaluate ex ante, cven when the set of functions is welldefined (both for the clicnt and for the firm), and will depend on the type of technology being used, the ability and the cxperience of the staff of the two companics. Third, with the best of staff and the clcarest of goals there is also the risk that some uncxpected problem arises and delays or destroys the project. Finally, not all firms try their hardest to control costs and delays and onc would cxpect that some projects will end up costing much more than they ought to.

Table 1 shows cvidence from our intervicws confirming that overruns are indeed common: it turns out that $74 \%$ of the projects are completed with a positive ovcrrun. The averagc overrun amounts to $24 \%$ of the initial cstimatc, and varics a lot (its standard deviation is $34 \%$, and the maximum ovcrrun in the sample is $250 \%$ ). According to the firms, overruns are duc mostly to changes required by the client (thesc changes causc $48 \%$ of the overrun on average). Another $20 \%$ of the overrm is duc to initial ambiguity in the specifications (i.c., to cases where the firm did not understand what the clicnt really wanted), $8 \%$ is duc to internal difficultics in the firm (the most frequent one being the loss of the project manager in the middle of the way) and $13 \%$ to delays occasioned by the clicnt. Very few projects (less than $5 \%$ ) are completed with a negative ovcrum, and the mcan overrun is clearly not zcro.

Both firms and clicnts are, of course, aware of the possibility of overruns. ${ }^{19}$ Overruns, apart from being wasteful in themsclves (in so much as they could have becn avoided by both partics bcing more diligent), lead to delays which are costly ${ }^{20}$ and are a potential source of conflict between the client and the firm (conflicts arise when each side blames the other for the overrun).

Vertical integration and contracts are two ways of limiting the wastc duc to overrun. Many foreign companies have set up $100 \%$ owned subsidiaries in India. ${ }^{21}$ These subsidiaries are $100 \%$ cxport oriented, and carry out work for thcir mother company and in some cascs, for other clients as well. A number of Indian software firms have also entered into arrangements under

\footnotetext{
${ }^{19}$ For cxample, the template of a firm's contract spccifics that "the cffort cstimates provided for the conversion and testing phases of this project have becn provided by the software firm on a best cstimate basis. If the scopc of the effort changes as a result of discussions during the detailed design phase, the software firm will analyzc the impact of clianges on the project and may present revised schedules and costs. Changes in schedules and costs resulting from such clianges will be reflected by an amendment to this contract."

${ }^{201}$ Delays, while rarer than overrun, are far from uncommon in our sample: there arc delays in $19 \%$ of the cases, and in $25 \%$ of the cases where there was an overrun.

${ }^{21}$ Including AT\&T, IBM, Microsoft, INTEL, ORACLE, Fujitsu and Motorola.
} 
which the firm dedicates a part of its employecs, office space, and computers to a single forcign clicnt. This is what is called an "Off-shore Softwarc Development Center" (OSDC). The client scnds a steady fraction of his software development necds to the firm, and is responsible for making use of the facilitics devoted to him. This is in effect a type of vertical integration: the OSDC becomes virtually a unit of the client for whom it works regularly. In such cases the interests of the firm and the clicnt are clearly better aligned and while there may be overrun, there is much less reason why the overrun should be wasteful. ${ }^{22}$

Since we are interested in contracts rather than vertical integration our focus in this paper is mainly on cxternal contracts (i.c., contracts that are performed neither within OSDC nor for the mother companies of the firm). We obscrve the following types of external contracts: Under fixed-price contracts, a fixed price is agrecd upon up-front, beforc the specification analysis. These contracts are by far the most frequent: $58 \%$ of external contracts are fixed-price contracts. Under mixed contracts the price is fixcd for the spccification phasc only at the beginning of the process. The price for the complete project is fixed only when specifications are written and more is known. Typically in such cases the requirement analysis is paid for on a time and matcrial basis, though this is not nccessarily the casc. Under time and material contracts, the cntirc product is paid for on a time and matcrial basis. These contracts are the least frequent among cxtcrnal contracts (15\%). A striking fact is that there appcars to be no "intermediate" contracts: all contracts belong to onc of these threc categories. ${ }^{23}$ For cxample, there are no contracts where the clicnt and the firm agrec on sharing the costs. ${ }^{24}$

While these contracts predict extreme outcomes in terms of cost-sharing, we actually do not always obscrve this. It turns out that a large fraction of contracts get rencgotiated ex post. This is cvident from Table 2, which shows the fraction of overrun paid for by the firm and the proportion of firms that pay all or nothing of the overrun for the threc types of contracts. Even in fixed-price contracts, the actual overrun is often shared between the client and the firm (in $46 \%$ of the cascs) whilc firms with time and matcrial contracts sometimes pay for overrun (in

\footnotetext{
${ }^{22}$ Indecd there may be morc overrun in such cases than in gencral preciscly becausc ovcrrun cntails less wastc. For example, the client may not necd to be very precisc about what he wants since he knows that the firm will be happy to do whatever is asked of it.

${ }^{23}$ Or their variants: in some cascs property rights in the product substitutcs for cash payments.

${ }^{24}$ Such contracts are obscrved, albeit rarely, among the procurement contracts for airplane engines studicd by Crocker and Reynolds (1993).
} 
$22 \%$ of the cases). However it is also clear from the figures in Table 2 that the initial contract has an clcar influence on which party bears the risk of the project: in fixed-price contracts, firms bear on average $63 \%$ of the overrun, while they bear on average $51.5 \%$ in mixed contracts and $15.5 \%$ in time and matcrial contracts. Since fixcd-price contracts dominatc our sample, this cridence also implics that firms bear a lion's share of the overrun (57\% on average for cxternal projects, $76 \%$ for the median external project). Since firms are typically much smaller than their clicnts, this is at lcast somcwhat surprising.

There are several potential cxplanations for the pervasiveness of renegotiation. First, even when a firm faces a fixed-price contract it may have some bargaining power because it usually has the option of walking off the job. If it docs, it will not get paid for work that it has alrcady donc, but it will also avoid the overrun and, at least at carly stages of the job, the sccond cffect may dominatc. Second, the court system in India is extremely incfficient and going to court is very costly. Firms and clicnts will therefore prefer to make some concessions in order to avoid going to court. In fact, there is no project in our sample where the firm and the client went to arbitrage court (cren though in some occasions the firm reports a conflict with the clicnt). More gencrally, from our conversations with industry pcople we have the impression that pcople go to court very rarcly and therefore we ought to cxpect some rencgotiation.

Finally, firms and clicnts may voluntarily pay for any overrun that is of their own making, because they carc about their reputation for bcing reliable. We had a number of conversations where the CEO of the firm told us 'it was our fault and we paid for it'. Wc also have some more indirect cvidence that this is at least sometimes the casc: as mentioned above, we asked firms questions about who was responsible for the overrun. In what follows, we assume that the firm is responsible for what it described as changes duc to ambiguitics and overrun caused by internal difficultics. Changes requircd by the clicnt and delays coming from the clicnt's side arc taken to be caused by the clicnt's responsibility. Table 3 shows the share of ovcrun paid by the firm when the overrun is entirely due to the clicnt (column (1)), cntircly due to the firm (column (3)), or duc partly to both (column (2)). In column (4), we prescnt the cocfficient of an OLS regression of the sharc of overrun paid by the firm on the share of overrun which it causcd. In all types of contracts, firms always pay more of the overruns entircly caused by their own mistakes compared to the overrun entircly due to the client. Moreover, in all cases but one, the share of ovcrrun paid by the firm lics inbetween these two numbers when the overrun is partly 
causcd by cach side. Furthermore, the OLS regressions indicate that, regardless of the initial contract, the larger the fraction of the overrun that a firm has caused, the larger the share it has to pay (if a firm causes one additional percent of the overrun, it bears approximately 0.20 percent more of it).

In the next scction we present a model of the industry which is based on the picture that cmerges from the above discussion. The main clcments we wish to capture in our model are the following:

- the high levels of overrun,

- the fact that both sides are responsible for overrun,

- the use of simple ex ante contracts,

- the fact that the contracts get renegotiated ex post,

- the fact that the ex ante contract continues to influcnce the renegotiatcd outcome,

- the fact that firms and clients care about thcir reputation for being rcliable and will often voluntarily pay for ovcrrun that is of thcir own making.

\section{A Model of the Software Industry}

The model we propose in this scction is an attempt to capture in as simple a way as possible what, on the basis of our experience in the industry, we sec as the fundamental structures and conflicts in the Indian customized software industry. The contracting outcomes that will be predicted by the model will, as we shall sec, match up reasonably well with what is obscrved in the data. However, one could come up with other models, or at least combinations of other modcls, which also cxplain the data. We will discuss some alternative cxplanations in Section 5. In the end, however, it remains plausible that clements of thesc other models could also be a part of any comprchensive story of the software industry in combination, perhaps, with the story we tell. In this sense, the model is meant to be illustrative rather than definitive.

The premisc of the model is that software projects are prone to cost overruns and that the main conflicts arc over the apportioning of these cost overruns. Overruns can happen for two reasons. First, the client could have becn insufficiently diligent in delineating his requirements 
or he could have made a mistake. As a result, when the firm comes up with a product he might realize that this is not what he wants and demands changes. The firm is, of coursc, happy to make the changes - since they arc Parcto improving - but only if it is adequately compcnsated. The issuc is whether the clicnt will be willing to compensate it cnough. Second, overruns could also happen because the firm was cither lazy or unlucky in the way it carried out the project.

Since the overrun could come from cither side, when there is an overrun, there is a real possibility that cach side will blame the other for it. This necd not be a problem if outsiders, and specifically the courts, can obscrve who was rcally responsible. Our assumption will be that this is not possible in most cases.

This is clcarly something of a caricaturc of reality: firms and clicnts clcarly do try to set up systems to cnsurc that it is clcar, ex post, who was to blame for any overrun. The procedure of defining deliverables and having the client sign off on cach deliverable is onc such system. Once a clicnt signs off on a deliverable, he is to a large cxtent committed to admit that at least up to that point the firm had done what it was supposed to do. This clearly limits the scope for future disagrecments. Nevertheless, there scem to be lots of disagrecments and this is presumably ascribable to the fact that even after many milestones have becn reached, there remains substantial ambiguity about what cxactly necds to be donc.

\subsection{Disagreements, Overrun and Contracts}

We capture the possibility of this kind of disagrecment as follows. The client $(C)$ wants the firm $(F)$ to build a picce of software that will be worth $V$ to the clicnt (we will assume risk-ncutrality on both sides throughout, so this is best thought of as a moncy payoff and the costs as moncy costs). In a world where the client can describe the product it wants perfectly and the firm also understands this description perfectly, the project should cost $\bar{y}$ (i.c., the estimate is $\bar{y}$ ). We adopt the normalization that $\bar{y}=0$.

However we assume that in every project the actual cost will be positive, i.c., there will be overrun: the client's description of the project will always be incomplete and the firm will never understand it perfectly. Total ovcrrun will thus be the sum of overrun caused by the firm $\left(y_{F}\right)$ and overrun causcd by the client $\left(y_{C}\right)$. Assume that all overrun is initially paid for the by the firm. 
The amounts of the ovcrum, $y_{F}$ and $y_{C}$, are detcrmined, respectively, by the effort put in by the firm and the clicnt in describing and understanding the project. Specifically we assume that firms face a choice between a high level of $y_{F}, \overline{y_{F}}$, and a low level, $\underline{y_{F}}$. Likcwisc, the clicnt faces a choice between $\overline{y_{C}}$ and $\underline{y_{C}}$. Cetcris paribus, botls firms and clients prefer high levels of ovcrrun - this may be becausc controlling overrun takes cffort or becausc the firm (or the clicnt) gets to kecp a part of the overrun it has generated (say the firm is lying about its costs). The cxtra private benefits to the clicnt and the firm of a high level of overrun are, respectively, $B_{C}$ and $B_{F}$. Assumc that $\overline{y_{C}}-\underline{y_{C}}>B_{C}$ and $\overline{y_{F}}-\underline{y_{F}}>B_{F}$ so that it is always cfficicnt to minimizc ovcrrun.

However, we will assume that both $y_{C}$ and $y_{F}$ are known only to the firm and its clicnt: third partics such as the courts only obscrve total overrun $\left(y_{C}+y_{F}\right) .{ }^{25}$ Morcover, we restrict all contracts to bcing lincar and in addition require that they do not involve throwing away any moncy. In other words, we only consider contracts where the clicnt pays the firm an amount $P+(1-s)\left(y_{F}+y_{C}\right)$ - wherc $P$ is a pre-specificd fixcd payment and $s$ is the share of the overrun borne by the firm $(s \in[0,1])$ - and neither party makes any payments to anybody clsc. Of particular interest to us will be two extreme contracts: the contract with $s=1$ (corresponding to a fixcd-pricc contract) and the contract with $s=0$ (which corresponds roughly to a time and matcrial contract). ${ }^{26}$ It will be key to our analysis that ncither of these contracts obviously dominates the other. The fundamental trade-off comes from the fact that $s$ is one number that is being used to give incentives to both partics: a high $s$ will give good incentives to the firm but not to the client, while a low $s$ contract does the reverse. As a result, it will typically not be possible to implement the first best. ${ }^{27}$

To complete the description of the contracting process we necd to say who proposes the contract. Our reading of the industry practice is that the contract is usually proposcd by the

\footnotetext{
${ }^{2 \pi}$ In other words, the fact that, say, two pcople were assigned to the project for 14 wecks is verifiable but not what they were actually doing - they could have becn really working on a different project for most of that time.

${ }^{26}$ The correspondence is not exact because a time and material contract typically pays a markup on the realized costs rather than a fixed payoff. Similar results hold for that case but the exposition is somcwhat more cumbersome.

${ }^{27}$ This basic tension is very gencral. Our restriction to linear contracts, while vital in the discrete case we have chosen here, can be relaxed if we are preparcd to go to the model where overrun varies continuously: the impossibility of implementing the first best in that case is a consequence of the results in Holmstrom (1982).
} 
firm. We will make this our maintained assumption, noting however that similar results would hold if we allowed the client to propose the contract.

\subsection{Norms}

When the first best cannot be achieved by contractual means, it is possible to improve on the outcome if the bchavior of the fims and the clicnts is at least partly norm-governed. Specifically assume that there are two types of firms and two types of clicnts. Of these, one type of firm and onc type of clicnt obscrves a norm of being reliable, by which we mean that they always pay for any overrun that they themsclves have generated, as long as the other side does the same. In particular, they will pay for the ovcrrun that they have gencrated, even if the contract stipulates that the other side pays for it - in other words they do not necessarily maximize current profits. However, if the other side does not act reliably they do not act reliably cither - they simply try to maxinizc current profits. Assume by contrast, unreliable firms and clients always act to maximize their current profits.

When a firm and a clicnt are matched, they do not directly observe cach other's types. Rather they assign probabilitics to the other party being rcliable, on the basis of what they know about them. The probability that the firm puts on the clicnt's being reliable, $\theta_{C}$, and the probability that the clicnt puts on the firm's being likewisc, $\theta_{F}$, therefore summarize their respective reputations. We will return to the question of how these reputations arc sustained and their crolution later in this section.

\subsection{Contracts for Protection}

In this sctting, since the reliable firms and clicnts are going to be sclf-regulated, the function of the contract is to protect reliable clicnts against opportunism by unreliable firms and vicc versa. The contract protects because it provides a fall-back option when the other party is being unrcliablc. If a firm, for cxample, gencrates a largc amount of overrun and refuscs to pay for it, it can be taken to court and forced to pay at lcast the share of the overrun it has contracted to bcar.

However as we have alrcady argucd in Section 2, we expect thesc contracts to be rencgotiated. Wc assume that the renegotiated outcome is a sharing of the overrun which is potentially different 
from what is in the contract and is represented by the share of the overrun paid for by the firm when there is a dispute, $s^{*}\left(s, \theta_{C}, \theta_{F}\right)$. It is natural to assume that $s^{*}$ is incrcasing in $s$. We would also expect that more reputed partics will have more bargaining power and therefore pay less (bccause, for cxample, the court will pay more attention to their plaints but also becausc other determinants of bargaining power such as creditworthiness tend to be correlated with reputation), i.c., $\frac{\partial s^{*}}{\partial \theta_{C}}>0$ and $\frac{\partial s^{*}}{\partial \theta_{F}}<0$. Assume also that $s^{*}$ is bounded below by $\underline{s^{*}>0 \text { and }}$ above by $\overline{s^{*}}<1 .^{28}$

\subsection{Firm Behavior}

Rcliable firms and clicnts always pay for any overrun that they gencratc. It follows that they always choose a low kevel of overrun - $\underline{y_{F}}$ for the firm and $\underline{y_{C}}$ for the clicnt. At the end of the contracting period they observe the overrun generated by the other party and also whether or not they agrec to pay for it. If the other party refuses to pay for the orerrun it has generated there is a dispute: then the firm and the clicnt cnd up sphitting the overrun in the ratio $s^{*} /\left(1-s^{*}\right)$.

Unreliable firms want to maximize their short run carnings. They have four options: to mimic the reliable firms and choose $\underline{y_{F}}$ and to pay for all of it as long as the clicnt behaves reliably and to go to the dispute outcome otherwise; to choose $\overline{y_{F}}$ but to act reliably in all other respects (i.c., to pay for all of it as long as the client behaves reliably and to go to the dispute outcome otherwise); and to choose cither $\underline{y_{F}}$ or $\overline{y_{F}}$ and to go directly to the dispute outcome.

Unrcliable clicnts also want to maximize short run carnings and face a similar trade-off. The actual choice made by unreliable firms and clients will depend on the $s$ that is written into the contract, as well as on what they expect the other side to do. The following proposition gives conditions under which unreliable firms and clients indecd are unreliable i.c., choose a high level of overrun and then get into a dispute:

Claim 1 The unique equilibrium behavior of unreliable firms and clients is to choose $y_{F}=\overline{y_{F}}$ and $y_{C}=\overline{y_{C}}$ and go the dispute outcome subsequently, as long as the two following conditions hold:

\footnotetext{
${ }^{2 \times}$ Given that wc have assumed risk ncutrality, the natural interpretation for $s^{*}$ is that it is the expected share of the overrun borne by the firm in the event of a disputc. The actual share will presumably vary according to cxact circumstances of the negotiation process, and, on occassion, may turn out to be 1 or 0.
} 


$$
\begin{aligned}
& \text { (i) } \overline{s^{*}}\left(\overline{y_{F}}-\underline{y_{F}}\right)<B_{F} \text { and }\left(1-\underline{s^{*}}\right)\left(\overline{y_{C}}-\underline{y_{C}}\right)<B_{C} \\
& \text { (ii) } \underline{y_{F}} \text { and } \underline{y_{C}} \text { are both sufficiently close to } 0 .
\end{aligned}
$$

Thesc conditions are not necessary for there to be an cquilibrium with unreliable behavior but they have the advantage of being casy to interpret. The first condition essentially says that even if it were possible to give incentives separately on $y_{F}$ and $y_{C}$, neither party could be induced to make their first best choice purcly on the basis of those incentives - simply because in our setting renegotiation rulcs out the most cxtreme contracts $\left(s^{*}=0\right.$ or $\left.s^{*}=1\right)$. The sccond condition illustrates an additional source of incentives that arises because of the specific structure wc assume - by choosing to disputc, the disputant necessarily takes on responsibility for some part of the overrun generated by the other party. If the other party was reliable, he could have avoided this part of the overrun by bchaving reliably himsclf. This might give him a reason to bchave reliably. The sccond condition in effect rulcs out this particular source of incentives, since it says that if the other party is reliable his contribution to overrun is very small.

For most of this section we will assume that both these conditions hold and, conscquently, unreliable firms and clients choose high levels of overrun and then go to the dispute outcome. We realize that the first of these conditions is actually quite stringent. However we will suggest later that our results on contractual choicc do not really turn on this property: it is simply convenient, since it limits the number of possible cases.

\subsection{Matching}

For most of this scction we assume that firms and clicnts are matched randomly with cach other. This of course docs not apply to the clicnts who are going back to a firm that they have already worked with - there the question is whether the original match was more or less random. Even in the more common casc of first time matches, howcver, onc may expect some sclection, especially since - as will be pointed out later - there are bencfits from matching appropriatcly. The possibility of sclective matching is, however, limited by the fact that clicnts often have quitc specific necds and the number of firms with the capacity to mect those needs at any point of time, may be quitc small. Morcover, clicnts often rely on hearsay in sclecting which firms to approach with a request for proposal and this may imply more or less random sclection from 
the point of vicw of cverything that is publicly obscrvable. In such cases, random matching may not be a bad approximation to the truth.

\subsection{Reputation}

Reputation in our model is reputation for bcing reliable. There arc at lcast two possible interpretations of what makes a firm rcliable. In onc interpretation it is an intrinsic property of the firm (i.c., the owner of the firm genuincly prefers to be reliable rather than rich) and some firms have it and others do not.

In a sccond interpretation, all firms are greedy, but some are paticnt and therefore able to lestrain their grecd in favor of better long term outcome and the rest are impaticnt (or have more pressing immediate necds). In other words, reliable firms and clicnts play a strategy that corresponds to a good equilibrium of a repeated game while the unreliable play stratcgies that maximize short run profits. Clearly this would only work if there is some mechanism by which the history of past behaviors becomes public. We therefore posit that if a firm or a clicnt has becn uncliable in the past, with some probability it becomes public information at some point in the futurc. ${ }^{29}$ The good cquilibrium is sustained by the thrcat (say) that no firm will contract witl a client who is known to have becn unreliable in the past and vice versa. ${ }^{30}$

Under cither interpretation, there are several mechanisms by which reputation can evolve. First, in those cases where the firm and the client have contracted at least once before, the presumption is that both had bchaved reliably so that they both now have a better reputation vis a vis the other. ${ }^{31}$ Forty-one percent of the contracts in our sample involved a clicnt with whom the firm had worked already. This proportion is roughly the same among young and old firms.

Sccond, the age of the firm should be a sourcc of reputation. Wc have alrcady assumed that if a firm or a client has becn unreliable, with some probability this bccomes public information at some time in the future. Once that happens no one will want to contract with it any more since it is known to be unreliable and it will probably end up exiting from the industry. ${ }^{32}$ This

\footnotetext{
${ }^{29}$ This might happen becausc a disgruntled employec reports what really happened or an incriminating document gets to the wrong hands.

${ }^{30}$ This formulation closcly follows Tirolc (1996). Sce also Kandori (1992).

${ }^{31}$ For an cxplicit model of how reputation cvolvcs within a spccific rclationship, scc Rauch and Watson (1999).

${ }^{32}$ Under our sccond interpretation above, the equilibrium stratcgics actually dictate that no one contracts with
} 
sclection process ensures that older firms (and clicnts) will typically be more reliable. This is reinforced by the fact that information is revealed over time and therefore a firm that has becn in the industry a long time and docs not have any black marks against it, is more likely to be reliable. Fifty-seven percent of the firms in our sample were created in 1993 or after.

Finally, firms may be able to cstablish a reputation by demonstrating that they follow processcs which, in principle, should reducc overrun. Process certification by outside agencies, such as ISO 9000 certification, are thereforc another potential source of reputation. ${ }^{33}$ As we noted in the introduction, firms in the industry are currently very kecn to acquirc ISO ccrtification, preciscly becausc they think that it will improve their reputation. Ninctecn percent of the cxternal contracts in the sample were done by ISO-certificd firms. ISO-certificd firms tends to be older firms (only $9 \%$ of the young firms have ISO certification).

\section{Theoretical Results}

\subsection{The Optimal Contract}

Since we have assumed that it is the firm who proposes the contract, and the firm knows its own typc, the proposed contract can be used as a signalling devicc - a firm that plans to bc unreliable will prefer a contract where it pays very little of the overrun and thercfore, by choosing to absorb most of the ovcrrun a firm may be able to signal that it is reliablc. Given that we are in a signalling cnvironment, we will expect that there will be many cquilibria. However all such cquilibria will involve pooling since in a scparating cquilibrium all the unreliable firms and clicnts would be worsc off than they would be pretending to be reliable.

Among the set of pooling cquilibria we focus on contractual outcomes where the total joint a firm or a client that is known to have bchaved unreliably. Under the first interpretation firms and clients that arc known to be unrcliable should still make less moncy and thercforc should be more likcly to cxit.

${ }^{33}$ ISO certification is awarded by international or Indian agencies, themsclves accredited, which examine that the processes of software production in the firm follows some approved routines. In particular, the firm must follow specificd procedures to report on the progress of the software and to perform the tests. Conscquently, the software development process should be casier to monitor for ISO certificd firms. Morcover, ISO certified firms are monitored crery once in a whilc, and lose the certification if they cannot prove that they followed the approved methods. This should give strong incentive to the ISO certified firms to stick to standard procedures and report problems reliably. 
surplus of a firm and a client who are both reliable is maxinized. This is always a BaycsianNash equilibrium (sustained by the belief that only opportunists deviate). The fact that it is also Parcto optimal from the point of vicw of the reliable types makes it an olvvious focal outcome.

This cxpression for joint surplus is:

$$
\begin{gathered}
W\left(s, \theta_{C}, \theta_{F}\right)=V-\theta_{F} \underline{y_{C}}-\left(1-\theta_{F}\right)\left(1-s^{*}\left(s, \theta_{C}, \theta_{F}\right)\right)\left(\underline{y_{C}}+\overline{y_{F}}\right) \\
-\theta_{C} \underline{y_{F}}-\left(1-\theta_{C}\right) s^{*}\left(s, \theta_{C}, \theta_{F}\right)\left(\underline{y_{F}}+\overline{y_{C}}\right) .
\end{gathered}
$$

The third term in this cxpression gives the total surplus that is lost because in a pooling equilibrium a reliable client must allow for the possibility that the firm is unreliable, while the fifth term is the surplus that is lost bccausc the firm must allow for the possibility that the clicnt is unrcliable.

To find the optimal contract we need to maximize the above cxpression for $W$. Differentiating IV with respect to $s$ gives us the cxpression:

$$
\left[\left(1-\theta_{F}\right)\left(\overline{y_{C}}+\underline{y_{F}}\right)-\left(1-\theta_{C}\right)\left(\overline{y_{F}}+\underline{y_{C}}\right)\right] \frac{\partial s^{*}}{\partial s}
$$

This cxpression is positive if and only if $\left[\left(1-\theta_{F}\right)\left(\overline{y_{C}}+\underline{y_{F}}\right)-\left(1-\theta_{C}\right)\left(\overline{y_{F}}+\underline{y_{C}}\right)\right]>0$. The fact that this last cxpression is independent of $s$, decreases in $\theta_{F}$ and increases in $\theta_{C}$ gives us:

Claim 2 The optimal contract is always either a fixed price or a time and material contract (s is either 0 or 1$)$. It is a fixed-price contract when most clients are reliable while firms are more likely to be opportunists, and a time and material contract in the reverse situation.

This accords well with the fact, reported above, that these are the only two types of contracts. ${ }^{34}$ It also confirms the intuition, given above, that fixcd-price contracts are instituted to protect clicnts against opportunism, whilc time and matcrial contracts protect firms. Firms that have a high reputation will get time and material contracts while the rest of the firms will not.

\footnotetext{
${ }^{34}$ The reader may fecl that the result that the contracts are always at one or other extreme is driven by the assumption of risk-ncutrality. This is partly true, in the sense that if the two partics are sufficiently risk-averse a less extrene contract will be chosen. However note also that $s^{*}$ is always strictly between zero and one - the effective contract is never very extreme. Therefore it may well be the case that the initial choice of an extreme contract is consistent with optimal risk-sharing.
} 


\subsection{The Sharing of Overrun}

The expected share of the overrun paid by the average firm with reputation $\theta_{F}$ that works for a clicnt of reputation $\theta_{C}$, is:

$$
\theta_{F} \theta_{C} \frac{\underline{y_{F}}}{\underline{y_{F}}+\underline{y_{C}}}+\left(1-\theta_{F} \theta_{C}\right)\left(s^{*}\left(s, \theta_{F}, \theta_{C}\right)\right)
$$

In the previous section we showed that the optimal $s$ is a decreasing function of $\theta_{F}$. Therefore an increase in $\theta_{F}$ reduces the share of the overrun paid for by the firm both through its direct effect on $s^{*}$ and through its effect on $s$. An increase in $\theta_{F}$ also shifts wcight from the sccond term in the above expression to the first term. The effect of this shift depends on the relative sizes of $s^{*}$ and $\frac{\underline{y_{F}}}{\underline{y_{F}}+\underline{\underline{y_{C}}}}$. For firms with a rclativcly low reputation, the contract is likcly to be a fixed-price contract and $s^{*}$ will be high. Therefore this third effect is likely to also be negative or even if it is positive it should be small. For very reputed firms, however, this effect might be negative and could in principle be negative cnough to counteract the two other effects: for such firms an increase in their reputation may actually increase their share of the ovcrrun. To summarizc:

Claim 3 If two firms are matched with clients who have the same reputation, the firm with the higher reputation is likely to bear less of the overrun on average. The one case where this relation nay not hold is for very reputed firnis. With randon matching, the negative relation between reputation and the share of overrun also holds without controlling for the reputation of the client.

The mean overrun gencrated by a firm of reputation $\theta_{F}$ is given by the expression:

$$
\theta_{F} \underline{y_{F}}+\left(1-\theta_{F}\right) \overline{y_{F}} .
$$

This is clcarly decreasing in $\theta_{F}$. Likcwisc, the ovcrrun gencratcd by a clicnt is decreasing in the clicnt's reputation. With random matching, since the reputations of the two partics are independent, it follows that the total overrun is also decreasing as a function of the reputation of the firm.

Claim 4 The overrun generated by the firm (client) decreases with the firm's (client's) reputation. With random matching, the total overrun generated in a relationship is also decreasing in the firm's reputation. 


\subsection{Extensions of the Model}

\subsubsection{Non-random Matching}

The assumption that firms and clients match at random is clearly indefensible for the case where there is a repeat match. A repeat match clcarly signals high levels of mutual respect - in other words compared to the initial match between them, both $\theta_{C}$ and $\theta_{F}$ ought to be higher. The direction in which the new contract will differ from the initial contract is therefore potentially ambiguous. However it may be reasonable to assume that since there are many more start-ups among firms than among the clients ${ }^{35}$, the firm's reputation will improve by more than the clicnt's reputation. In this case, the new contract will be more likely to be a time and material contract. The firm's share of the overrun should also go down.

The assumption of random matching is questionable even for first time matches. Firms with low reputations expect to get a fixcd-price contract. Therefore, they have the most to lose from being matched with a clicnt who has a low reputation. Formally this is captured by looking at the properties of the function

$$
\begin{aligned}
& W^{*}\left(\theta_{C}, \theta_{F}\right)=\max _{s} W\left(s, \theta_{C}, \theta_{F}\right) \\
& \left.=V-\theta_{F} \underline{y_{C}}-\left(1-\theta_{F}\right)\left(1-s^{*}\left(s\left(\theta_{C}, \theta_{F}\right)\right), \theta_{C}, \theta_{F}\right)\right)\left(\underline{y_{C}}+\overline{y_{F}}\right) \\
& \quad-\theta_{C} \underline{y_{F}}-\left(1-\theta_{C}\right) s^{*}\left(s\left(\theta_{C}, \theta_{F}\right), \theta_{C}, \theta_{F}\right)\left(\underline{y_{F}}+\overline{y_{C}}\right) .
\end{aligned}
$$

Now if $\theta_{C}$ is greater than $\theta_{C}^{\prime}$

$$
\begin{aligned}
& W^{*}\left(\theta_{C}, \theta_{F}\right)-W^{*}\left(\theta_{C}^{\prime}, \theta_{F}\right)=\left(1-\theta_{F}\right)\left(s^{*}\left(s\left(\theta_{C}, \theta_{F}\right)\right), \theta_{C}, \theta_{F}\right) \\
& \left.\left.\quad-s^{*}\left(s\left(\theta_{C}^{\prime}, \theta_{F}\right)\right), \theta_{C}^{\prime}, \theta_{F}\right)\right)\left(\underline{y_{C}}+\overline{y_{F}}\right) \\
& -\left(\theta_{C}-\theta_{C}^{\prime}\right) \underline{y_{F}}+\left(\theta_{C}-\theta_{C}^{\prime}\right) s^{*}\left(s\left(\theta_{C}, \theta_{F}\right), \theta_{C}, \theta_{F}\right)\left(\underline{y_{F}}+\overline{y_{C}}\right) \\
& +\theta_{C}^{\prime}\left(s^{*}\left(s\left(\theta_{C}, \theta_{F}\right), \theta_{C}, \theta_{F}\right)-s^{*}\left(s\left(\theta_{C}^{\prime}, \theta_{F}\right), \theta_{C}^{\prime}, \theta_{F}\right)\right) .
\end{aligned}
$$

Ignoring terms that depend on the sccond derivative of the $s^{*}(\cdot)$ function (the last term in the above cxpression), the effect of an increase in $\theta_{F}$ on $W^{*}\left(\theta_{C}, \theta_{F}\right)-W^{*}\left(\theta_{C}^{\prime}, \theta_{F}\right)$ is unambiguously

\footnotetext{
$35 \%$ of the firms were created before 1993, while more than half of the client are fortune 500 firms or equivalent.
} 
negative. ${ }^{36}$ An unreputed firm (clicnt) bencfits more from being matched with a reputed client (firm) than a more reputed firm (clicnt).

While it is beyond the scope of this paper to explicitly model the matching process that lcads to this outcome, the implication of this result is that firms with low reputations should be more likely to be matched with reputable clicnts and vice versa. ${ }^{37}$ It is casy to sec that this kind of matching will reinforcc our results in Claim 2 about contractual choicc - the effects of a higher $\theta_{F}$ and a lower $\theta_{C}$ always go in the same direction.

Turning next to the average share of the overrun borne by the firm, $\theta_{F} \theta_{C} \frac{\underline{y_{F}}}{\underline{y_{F}}+\underline{y_{C}}}+(1-$ $\left.\theta_{F} \theta_{C}\right)\left(s^{*}\left(s, \theta_{F}, \theta_{C}\right)\right)$, we sec that the fact that higher $\theta_{F}$ 's are now associated with lower $\theta_{C}$ 's rcinforces the result given above in Claim 3 , since $s^{*}$ is increasing in $\theta_{C}$.

The effect of an increase in $\theta_{F}$ on total overrun is however no longer unambiguous in this casc. Whilc a less reputed firm generates more overrum, its partner, the more reputed clicnt, generates less, so the net effect may not be the one given in Claim 4.

We summarize these results in

Claim 5 Less reputed firms will try to match with more reputed clients and vice versa. This will reinforce our previous results on the effect of firm reputation on contractual choice and the sharing of overrun. Clients who work with less reputed firms will generate less overrun than clients who work with more reputed firms. As a result, total overrun is no longer necessarily decreasing as function of the reputation of the firm.

\subsubsection{Choice of Projects}

The fact that firms with low reputation pay for most of the ovcrrun should clcarly influcnce their choicc of projects. This can bc introduced into our model by making the plausiblc assumption that the most rewarding projects (the oncs with the highest $V$ ) will also have the highest possibility of largc ovcrruns ( $\overline{y C}$ and $\overline{y F}$ arc going to be largc). It is casy to show by introducing this assumption into the model of the previous section, that kecping the rcputation of the client fixcd, lcss reputed firms will be more willing to trade off a lower $V$ for a lower $\overline{y_{C}}$ than more

\footnotetext{
${ }^{36}$ This follows from the fact that $\left.\left.s^{*}\left(s\left(\theta_{C}, \theta_{F}\right)\right), \theta_{C}, \theta_{F}\right)-s^{*}\left(s\left(\theta_{C}^{\prime}, \theta_{F}\right)\right), \theta_{C}^{\prime}, \theta_{F}\right)$ is positive, while $s^{*}\left(s\left(\theta_{C}, \theta_{F}\right), \theta_{C}, \theta_{F}\right)$ gocs down when $\theta_{F}$ gocs up.

${ }^{37}$ Since we do not have data on client reputation we cannot dircetly test this prediction. We do observe that clicnt generated overrun is smaller for younger firms, which is consistent with this prediction.
} 
reputable firms. Formally this is scen by differcntiating the expression for $\mathbb{W}^{*}\left(\theta_{C}, \theta_{F}\right)$ with respect to $\overline{y C}$. This yiclds

$$
-\left(1-\theta_{C}\right) s^{*}\left(s\left(\theta_{C}, \theta_{F}\right), \theta_{C}, \theta_{F}\right)
$$

which is clcarly increasing in $\theta_{F}$ : less reputed firms bencfit more from a low $\overline{y C}$.

Here wc have assumed that it is possible to reduce $\overline{y_{C}}$ without affecting $\overline{y F}$. This is not especially implausible: Y2K projects arc sufficiently simple and standardized that the scope for client side opportunism is probably very limited. On the other hand the firm always has the option of simply doing the job lackadaisically. It is interesting nonetheless to look at what happens when a reduction in $\overline{y_{C}}$ is always accompanicd by an equal reduction in $\overline{y_{F}}$. Diffcrentiating the expression for $W^{*}\left(\theta_{C}, \theta_{F}\right)$ with respect to $\overline{y_{C}}$ and $\overline{y_{F}}$ yiclds the cxpression

$$
\left.-\left(1-\theta_{F}\right)\left(1-s^{*}\left(s\left(\theta_{C}, \theta_{F}\right)\right), \theta_{C}, \theta_{F}\right)\right)-\left(1-\theta_{C}\right) s^{*}\left(s\left(\theta_{C}, \theta_{F}\right), \theta_{C}, \theta_{F}\right)
$$

Differentiating this expression with respect to $\theta_{F}$, yiclds

$$
\left.\left(1-s^{*}\left(s\left(\theta_{C}, \theta_{F}\right)\right), \theta_{C}, \theta_{F}\right)\right)+\left(\theta_{C}-\theta_{F}\right) \frac{\left.\left.d s^{*}\left(s\left(\theta_{C}, \theta_{F}\right)\right), \theta_{C}, \theta_{F}\right)\right)}{d \theta_{F}}
$$

which, for low reputation firms, should be positive ( $\operatorname{sincc} \theta_{C}-\theta_{F}$ should be positive). This tells us that cren if $\overline{y_{C}}$ and $\overline{y_{F}}$ move together, the youngest firms will probably be among those who bencfit most from choosing a low $\overline{y_{C}}$ (and $\overline{y_{F}}$ ) project. ${ }^{38}$

Claim 6 Low reputation firms will tend to be specialized in projects which have low potential for client-side opportunism.

In terms of what we observe, this scems to suggest that low reputation firms will choose projects which are simple and well-understood so that the clicnt docs not have to do very much work to make clcar what he wants. Thesc projects can be cither short projects ${ }^{39}$, or projects where the main goal is casily defincd. Y2K projects are typical in this respect. ${ }^{40}$

\footnotetext{
${ }^{3 \times}$ Very reputable firms may also prefer projects with low $\overline{y_{C}}$ and $\overline{y_{F}}$ - the benefit in that casc comes from the fact that these projects protect the clicnts, who in this casc will be the vulncrable party.

${ }^{39}$ The complexity of a software project increases sharply with its sizc, sec Pressman (1997).

${ }^{10}$ Other projects where the objectives are relatively casily defincd include CAD projects and migration of an cxisting software from one platform to another.
} 
The possibility of switching to a low $\overline{y_{C}}$ project slould not affect the firm's share of the overrum in our model, since $\overline{y C}$ never chters the expression for the firm's sharc of the overrum. ${ }^{41}$ It does howerer makes it more likely that the results on the relation between reputation and mean overrun will be ambiguous. Becausc firms with low reputation will choose projects so as to limit overrun, clicnt generated overrun will be smaller when the firm has no reputation and therefore, total overrun may go up with reputation. Morcover, if thesc projects have also less scope for opportunism on the part of the firm, the mean overrun generated by the firm may not always fall with reputation.

\subsubsection{Contracts for Incentives}

Under the assumptions made so far, contracts only protect the contracting partics from opportunistic behavior on the other side. They have no direct incentive effects. We can add incentive effects to the model by assuming that when $s$ is chosen to be high enough, the resulting $s^{*}$ will be close cnough to 1 that even uncliable firms will prefer to act reliably. We also allow for the symmetrical possibility of inducing an unrcliable clicnt to act reliably by setting $s$ low cnough. We still rule out the possibility of getting the first-best outcome by assuming that in order to give any one side the incentive to be reliable, the other side has to be given very weak incentives.

In this casc, once $s$ is high cnough to induce reliable bchavior from unrcliable firms, there will be no rcason to raisc it further. In other words, the optimal contract may not be at the cxtremes. However it will still be the case that an increase in $\theta_{F}$ and a fall in $\theta_{C}$ will favor a contract with a lower $s$. On the other hand, since the least reputable firms in this world will never beliave unreliably, it turns out that for a certain spccific range of valucs of $\theta_{F}$ (those cxactly around the value at which the contract switches from a high $s$ to a low $s$ ) firms with lower $\theta_{F}$ will both gencrate less overrun and bear a smaller share of it, compared to firms with a ligher $\theta_{F}{ }^{42}$

\footnotetext{
${ }^{11}$ This is not strictly truc. A lower $\overline{y_{C}}$ and $\overline{y_{F}}$ may affect the choicc of the optimal contract and thercby affect the sharing of the overrun. Howcver, since most low reputation firms almost always have fixed cost contracts, this effect may not be very important.

${ }^{42}$ It should be noted that this perverse consequence of the incentive effect is most likely in model like ours where the firm (and the elient) make discrete choices. With a smoother set of choices, the incentive effect is never quite as dramatic and hence it may never be the casc that more reputable firms actually pay a higher share of the overrun.
} 


\section{Evidence}

In this section, we document that the central implications of the model are consistent with the data, by showing that contractual forms as well as the actual sharing of the overrun vary with characteristics likely to be correlated with the reputation of the firm. We then examine how the other predictions of the model match with the software data. Finally, we consider some obvious alternative explanations of the patterns obscrved in the data.

\subsection{Measures of Reputation}

We have already suggested threc altcrnative measures of a firm's reputation: its age, whetlucr or not it is in a repcat contract and ISO certification. ${ }^{43}$

We also make use of a fourth metric - we compare internal (projects for OSDC and mother companies) and cxtcrnal projects. We would cxpect the difference betwecn cxternal projects to be similar to the difference between first time and repeated relationships, for two reasons. First, there is clearly an clement of reputation: much like in a repeat contract but cven more strongly, the firm and the client must know much more about cach other (and what they know must be positive) if they have decided to establish a long term relationship together. ${ }^{\text {th }}$ Sccond, the scope for unreliable behavior in this type of relationship is much more linited, since both partics share the control rights. In other words, this kind of relationship is, in part, a substitute for reputation. However, we need to be sensitive to the fact that companies working for internal clicnts are potentially very different from other companies. In particular, OSDCs will be cstablished only after the clicnt has spent a very long time studying the firm. Fully-owned subsidiarics are often run by pcople who had becn previously working in the US office of the firm. We therefore restrict the comparisons to firms that perform some internal projects (c.g. subsidiaries that works for

\footnotetext{
${ }^{13}$ Note that we think of the reputation as being an attribute of the firm, more than of the individuals who compose it. It could be that an experieneed professional leaving his job to create a software firm takes his individual reputation with him. It turns out that individual reputation secms difficult to transport (we asked what the past career of the person who founded the software firm was, and examined whether this was related witl sharing of the ovcrrun, but did not find that this was the casc). The main reason is that the important input the CEO of a software firm has to provide is the management of the team, which may or may not be related to his ability as a software professional.

${ }^{11}$ The intcrual/external comparison is therefore closer to a repeated/first-time comparison than to a young/old comparison - since the matching in an internal project is like that in a repeat project.
} 
their mother company and also for cxternal client). This insures that the selection of firms for internal projects docs not invalidate the comparison (since all fims in this sub)-sample have becn sclected for some internal work).

\subsection{Choice of Contract and Sharing of the Overrun}

\subsubsection{Structure of the Contracts}

An implication of the model is that contractual forms will be restricted to contracts where the ex ante rulc is that firms will bear cither all or nothing of the cost ovcrruns. As pointcd out, this implication rests on the particular assumptions we have made, but it matches well with the obscrved pattern.

As we describe in Section 2, there are threc major types of contracts: fixed-price, time and material and "mixcd" contracts. Fixcd pricc contracts arc lincar contracts with $s=1$. As wc discuss above, timc and matcrial contracts arc similar to such contracts, with $s=0$. In mixcd contracts, the initial agrement specifies a payment for the specifications only. At the end of the spccification phasc, another agrecment is specificd for the development and testing phascs. This kind of contract cffectively splits the projects into two sub-projects. For each of them, a scparate sharing rulc is chosen, which is cither 1 or 0 (often, time and matcrial for the spccification phase and fixed-price for the subscquent work).

In other words, mixed contracts are a juxtaposition of fixcd-price and time and material contracts. It is casy to understand why, when the project is broken into these two phascs, specifications tend to be written on time and matcrial and the rest of the work tends to be done using a fixcd-price contract. In the specification phase, the potential for the clicnt to generate an overrun is cxtremely largc. In particular, when the firm first sends the specifications, he can pretend that the specifications written do not correspond to what he wanted. The whole cffort of the firm until that point becomes in cffect useless. Thercfore, it is important to give the clicnt higher powered incentive. On the other hand, at the time the sccond sub-contract is written, a large part of the uncertainty about what the client really wants is resolved, since he has agrecd (in writing) to the spccifications. Thercforc a fixcd-price contract, which give better incentives to the firm, can bccomc optimal from that point on. In practicc, the choicc of the contract for the sccond phase of the project is often endogenous: if the firm fecls that a substantial amount 
of uncertainty remains, it can in gencral insist on getting a sccond time and material contract. Mixed contracts are thereforc ex ante more constraining for the clicnt than for the firm.

\subsubsection{Reputation and the Choice of Contract}

The reputation of the firm determines both which contract it will get (choice of $s$ ) and what share of the ovcrrun it will cud up paying (actual $s^{*}$ ). Firms without a reputation will be more likcly to be have fixcd-price contracts than time and matcrial or mixcd contracts. Firms in fixcd-price contracts should bear more of the overrun than firms with other types of contracts. Finally, conditional on having any particular typc of contract, firms without a rcputation will bear morc of the overrun than firms with a reputation. The combined effect of thesc is, of coursc, that firms without a reputation will bear a larger share of the overrun. ${ }^{45}$

This sub-scction prescnts data relatcd to thesc implications.

We prescnted cvidence that age does matter in the introduction, as a motivation for this project. The relationship is illustrated in Figures 1 and 2. The proportion of fixed-price contracts and the share of the overrum borne by the firm are increasing with the foundation date of the firm. Table 5 shows the means of the firm's share of the overrun for cach type of firm, and the difference between low and high reputation firms. In column (1), we report the mean for the sample of cxtcrnal firms. In columns (2) to (4), we show the contrast betwecn young firms (created in 1994 or after) and old firms (created in 1993 or beforc). Young firms arc significantly more likcly to have fixed-price contracts (the probability is $26 \%$ higher). They also bear substantially more of the overrun both on average (19\%), and within the projects with fixed-pricc contracts (the difference is $13 \%$ ).

The pattern is less clcar for ISO ccrtification: ISO-certificd firms arc not less likcly to get fixed-price contracts and they do not pay for a lower fraction of the overrun in general. However, conditional on doing fixed-price contracts, they bear less of the overrun (20.4\%).

A rclationship with a client has the same cffect as a general reputation. Firms engaged in a

\footnotetext{
${ }^{45}$ It should be cmphasized that the full effect of reputation potentially includes things that are not necessarily the effect of reputation per sc. As pointed out above, the effect of reputation on the actual sharing of the overrun conditional on any particular initial contract, may include a bargaining power cffect because the detcrminants of bargaining power will tend to be corrclated with the detcrminants of reputation like age. In this sense, the cridence on the choicc of the initial contract tends to be "cleaner". This kind of conflation of reputation cffects and other effects is less likely to be the case when we arc comparing internal and external contracts.
} 
repeated relationship with their client are about as likcly as other firms to have fixed contracts, but they pay significantly less of the overruns (20\% less).

Finally, among firms who have internal contracts, firms pay for morc of the overrun when they deal with external clicnts than when they deal with internal clicnts. Almost half of their cxtcrnal contracts are fixcd-price contracts (a number close to the proportion of fixed-price contracts among old firms), whercas only $23 \%$ of the internal contracts are fixed-pricc contracts. They pay a much smaller share of the ovcrrun (20\% instcad of $47 \%$ ) in internal contracts than in cxternal contracts. The difference conditional on doing fixcd-price projects is not significant, but this is probably duc to the small number of fixed-price contracts among internal projects.

In summary, it scems that young firms, firms working with a new clicnt and firms working with an extcrnal clicnt bear a larger share of the overrun compared respectively to older firms, firms cngaged in a repeated relationship and firms working for an OSDC or their mother company. We interpret these results as showing that reputation docs influcnec the way the overruns are shared betwen the client and the firm. We will address some altcrnative cxplanations below; but the first possible carcat to this interpretation is that these firms do different types of projects, which require different types of incentives or entail different types of risk. For cxample if old firms do mostly project where there is a possibility of very large overruns, they may refuse to do the project unless they know they will be covered in case this happens. ${ }^{46}$ In particular, Table 4 shows that young firms, non ISO-certificd firms, and firms working for cxtcrnal clicnts do on arcrage smaller and simpler projects than old firms, ISO firms and firms working for internal clicnts. It is therefore important to check that the simple contrast between the groups is not an artifact of the different composition of their contracts.

In Table 6, we show the differences betwecn the overrun paid for by each type of firm in project-sizc cells (pancl B) and complexity cells (pancl D). ${ }^{47}$ The first pancl reproduces the uncontrolled difference of Table 5. In panel C, we show the "controlled contrast": this is simply a weighted average of the differences betwecn the young and old firms in the project size cclls, where the weights are given by the fraction of projects falling into this project sizc cell. This is a crude way to take into account the two facts that different types of firms choose different type of projects and that the differences across young and old firms are not necessarily the same for

\footnotetext{
${ }^{4(i W}$ will comment more on the choice of project per se below.

${ }^{17}$ We used the subjective complexity measure given by the firms.
} 
all project sizes.

Firms tend to bear less of the overrun when they do complicated projects than when they do simple projects. There is also a weak relationship between the size of the project and the share of the overrun paid for by the firm. Young firms pay a larger share of the overrun than old firms for small and large projects, but not for medium-sized projects. The controlled contrast between young and old firms is slightly smaller than the simple difference, but still high. The controlled contrast bccomes positive, though insignificant, for ISO-certified firms, mainly because the ISOccrtificd firms doing small projects do not pay any of the ovcrrum. ${ }^{48}$ Controlling for project size does not affect the difference between repeated and new clients and between internal and cxtcrnal contracts. Whatever the complexity of the project, young firms bear morc overrun than old firms, firms working with a new clicnt bcar morc ovcrun than firms working with a repeated clicnt, and firms bear less overrun when they do internal projects. The cvidence for ISO certification is, oncc again, mixcd.

In summary, cven after taking into account the size of the projects, firms with low reputation bear more of the overrun than other firms (although the cvidence in favor of ISO certification remains less than overwhclming).

A final picce of cvidence is presented in Table 7. In this table, we cxamine whether the different kinds of reputation are substitutes. Namcly, we ask in pancl A whether young firms still bear more of the overrun when they bencfit from another kind of reputation. In the table, we present the difference between young and old firms in the proportion of fixed-price contracts (line 1) and in the share of overrun they pay (line 2) within groups of ISO-certificd/non ISOcertificd firms, repcated/ncw clients, internal/cxternal contracts (for firms who do some jobs for internal firms). The contrasts are interesting. Non ISO-certificd young firms bear $27 \%$ more of the overrun than non ISO-ccrtificd old firms, but among ISO-certified firms, there is no difference. Young firms are significantly morc likcly than old firms to have fixed-pricc contracts if they work with a new clicnt, but not if they have alrcady worked with this client. Among firms that do some internal contracts, the same contrast appcars: young firms are morc likcly to have fixed-price contracts when they work with an external clicnt and pay for more of the overrun, but not when they work with an internal clicnt or an OSDC. ${ }^{49}$ In pancl B, we perform

\footnotetext{
${ }^{4 \times}$ This number should be taken with caution, as very few ISO firms do small projects.

${ }^{17}$ Jolinson, Mc Millan and Woodruff (1999) report comparable evidence in transition cconomics. Scllers arc
} 
the same excreise, but we look at how the difference betwecn the share of the overrun paid for by firms working with a new rather than repeated clicnt varics across different kind of firms. Interestingly, a very different pattern cmerges. The difference between new and repeated clicnts persists for old firms and for ISO-certificd firms, and docs not declinc. It suggests that the mechanism of reputation formation is rather incfficient: even after a firm has bcen in the market for some time, much remains to be lcarned about it.

We have documented systematic differences in the way cost overruns are shared across young and old firms, contracts with repcated and new clicnts, ISO-certificd firms and other firms, and firms in internal and cxternal contracts. This cridence is consistent with a model where reputation is an important determinant of the contracts and the sharing of the overrun. In the next subsction, we cxamine the whether the other cmpirical predictions of the model also hold.

\subsection{Further Results}

\subsubsection{Choice of Project}

A simple cxtcnsion to our model also predicts that the firms with a low reputation will tend to choose simpler projects where the objectives are easier to definc, which will tend to limit the overrun gencrated by the clicnt. We present cvidence relating to the choice of project in Table 4, and Figures 5, 6 and 7. Young firms do smaller projects (Figurc 6), which have smaller orerrun (cren cxpressed in proportion of predicted costs). ${ }^{50}$ They also tend to carry morc often "simple" projects (Y2K, CAD, data manipulation) (Figure 7), which generatc lower overruns, are casily defincd, and are casicr to monitor. We have also asked them to subjectively rate the complexity of the project, and even according to this subjective measure, young firms do morc simple projects (Figurc 5). As a result of these two combined facts, the returns from cach project (cost multiplicd by markup) is smaller on average for young firms than old firms.

This could be at least partly explaincd by the fact that young firms are on average less competent (and that thercforc clients do not want to cntrust them with large or complex projects). more willing to extend trade credit to a new customer if they have obtained information about him from a social or business network than if they have not, but the wcight given to this information declines as the length of the rclationship with this buycr increascs.

${ }^{i 0}$ Morcover, by doing that they kecp the share of overrun accounted for by cach project more or less similar across young and old firms: this could thereforc be cxplaincd by adding risk aversion to the model. 
However the same contrast liolds between internal and external projects (Table 4), for project size and Y2K projects. Since we have restricted the comparison to firms that do at lcast some internal work, the difference between internal projects and external projects is not tainted by this bias. This confirms that part of this difference between young and old is due to difference in bchavior.

\subsubsection{Overrun generated by the firm and by the client}

Our bascline model predicts that, on average, firms with a better reputation will gencrate less overrun (and therefore, total overrun will also tend to be smaller for their project). However, once we take into account non-random matching and the choice of projects, the prediction about the relationship between overrun generated by the firm and reputation are not unambiguous. On the other hand, thesc cxtensions predict that clicnts matched with firms with low reputation should generatc less overrun.

Table 8 presents cvidence on overruns generated by the firm and the elient. ${ }^{51}$ There is no systematic relationship between total overrum and the reputation of the firm: total overrun is smaller for young firms, firms without ISO certification, and cxternal projects; it is larger for firms dealing with a new clicnt. None of these contrasts is close to being significant. Overrun gencratcd by the firm is slightly larger for young firms and firms dealing with a new clicnt, but larger for ISO-certified firms and firms dealing with an internal client. ${ }^{52}$ Finally, overrun gencrated by the clicnt is smaller in all cases for less reputed firms, which is consistent with our argument that less reputed firms try to protect themsclves from absorbing large overruns by dealing with reliable clients or by choosing projects where the scope for clicnt gencrated overrun is smaller.

The data sccms consistent with our model of how reputation determines contractual outcomes. In the next scction, we examine the most obvious alternative cxplanation to the observed pattern.

\footnotetext{
${ }^{51}$ Overrun generated by the firm and overrun gencrated by the client do not neccssarily add up to total overrun: among sources of overruns proposed to the firms, there was an 'other' category, which we lcft unattributcd.

i2 These results could be consistent with the idea that overrun is slightly lower when firms have a good reputation. First, therc is in gencral no compclling cvidence that ISO certification rcally gives a firm a reputation. Sccond, as we have noticed already, overruns are less costly for internal projects, so they tend to be larger.
} 


\section{Alternative Interpretations of the Data}

This scetion revicws altcrnative cxplanations to the pattern observed in the data (in particular to the main result that young firms bear a larger share of the overrun than old firms).

\subsection{Pure Risk Sharing}

Onc possible interpretation of what is going on in this industry is pure risk sharing. However, as explained in much greater detail in a previous version of this paper, this interpretation very quickly runs into trouble. In the casc where we assume CRRA preferences (which is standard in cascs like this where there is substantial variation in the sizc of the contracting partics) we showed in the previous version of this paper that

Claim 7 If the firm and the client have CRRA preferences, for a fixed project size, the share of the risk that they each bear will be approximately in the inverse proportion of their coefficients of relative risk-aversion, keeping fixed the ratio of their total revenues. It will also be approximately in the direct proportion of their total revenues, keeping fixed the ratio of their risk-aversions.

Given that the client's revenues are much bigger than that of the firm, ${ }^{53}$ an implication of this proposition is that the client should bear most of the risk unless the client is much more risk averse than the firm. In fact, the firm bears on average morc than half of the cost ovcrrun, suggesting that the client's cocfficient of risk-aversion must be very large relative to the firm's. It is howcrer difficult to think of a basis for such differences in risk aversion. Morcover, this result has systcmatic predictions about the relationship between firm size and the sharc of the risk that it bears, controlling for clicnt size and project sizc. Table 9 presents the sharc of overrun paid by the firm by clicnt sizc, project sizc and firm agc. In all project sizc-clicnt sizc cells, old firms bear less of the overrun than young firms. Since old firms are on average larger (this is shown in Figure 4 and in columns 2 to 4 in Tablc 4: old firm's turnover is larger by $\$ 3.7$ million,

\footnotetext{
${ }^{5.3}$ More than half of the contracts in the sample are with "large" clients, $26 \%$ are with medium sized client, and $19 \%$ are with small clients. Large clients are in general fortune 500 companics or equivalent. Small clients are firms with turnover below $\$ 10$ million. In contrast, the median turnover of the software companies in the sample is only $\$ 1.2$ million, and the largest firm had a turnover of $\$ 47$ million. Only $27 \%$ of the firms have a turnover above $\$ 10$ million. Among the firms engaged in contracts with small clients, the median firm has a turnover of $\$ 0.5$ million.
} 
or more than $100 \%$, than young firms), this contradicts the basic implication of the risk-sharing model.

One might also speculate that old and new firms generate different risk profiles aud that this cxplains why old firms bear less risk: perhajss old firms simply gencrate less risk. However, the cridence on the standard deviation of total overrun presented in Table 8 shows that this is not the casc. The standard deviations of total project overrun are very similar across all types of firms. There is therefore no cvidence to support the vicw that young firms are systematically more risky to deal with. Another possibility, however, would be that the underlying distribution of orerrum is different for young and old firms (despite the fact that mean and standard deviation arc not different), and that the particular form of the risk faced by old firms made this particular risk sharing rulc optimal. We examined the cntirc distribution of overrun generated for both young and old firms (Figure 8). The two distributions are very similar, except for four old firms which generated very large overum (150\% and higher). These four old firms are however not driving the results, since all of them paid $100 \%$ of the overrun. Morcover, as we have shown above, the difference betwecn old and young firms is maintained when we control for project type (complcxity or sizc), which arc presumably good indicators of project-specific risk.

The cridence we give above strictly only applics to the case of CRRA preferences. There are, of course, many classes of risk preferences which do not fall into this catcgory. However, there are two basic intuitions which suggest that these other preferences will not work particularly wcll cither: on the onc side, if the cocfficient of absolute risk aversion falls faster than a CRRA, it is very hard to cxplain why the firm bcars any risk at all. On the other side, if the cocfficient falls slower than a CRRA (so that the preferences approach the CARA model), it can be shown that project size and client size effects also become smaller and this leaves very little to cxplain the inter-firm differences. ${ }^{54}$

\subsection{Varying Levels of Competence}

Our model has assumed that both clicnts and firms are risk-ncutral. Suppose we now assume that firms and clients make mistakes which lead to overrun but that thesc mistakcs can be contracted upon. In this case, one possible first best contract is one in which firms take the

\footnotetext{
${ }^{31}$ In the cxtreme case of CARA preferenees neither project size nor client size affects risk-sharing.
} 
full responsibility of any mistake that they makc. ${ }^{55}$ Now if young firms ${ }^{56}$ arc on average less competent, then it is to be cxpected that they would pay on average for more of the overrun.

The first point against this cxplanation is simply that risk-ncutrality is a very cxtreme assumption. If the firm was at all risk-averse then the optimal contract would try to insure the firm against all sources of risk that are beyond its control. Therefore, since young firms do not choosc to be incompetent, they should be insurcd against overrun that results from their mistakes. Of course, the cxtent of such insurance may well be limited by the client's willingness to bear risk, but as we have alrcady argucd, the clicnt is in a much better position to bcar risk than the firm, and in particular small firms should only bear a small part of the risk. Of coursc, this assumes that the mistakes are not made delibcratcly. The case of varying levels of moral hazard will be cxamincd below.

There arc also some simple cmpirical arguments against this vicw: first (and most importantly), firms pay much more of the overrun than the share for which they are responsible: as shown in Table 3, cven when the client is fully responsible for the orcrrun, the firms still pay on average $51 \%$ of it. Second, to explain the differences in the share of overrun paid by the firms cntircly by differences in the sharc of overrun that is causcd by the firm, it would have to be the casc that young firms causc substantially more overrun than old firms do. Recall that the total overiun is, if anything, larger for old firms than young firms. The difference between the share of overrun duc to young firms and the sharc of ovcrrun duc to old firms is clcarly not large cnough to explain the difference in the sharing of these additional costs. Differences in sources of the overrun are shown in Table 8 . The difference between the fraction of overrun duc to young firms and that duc to old firms is only $1.18 \%$, but they pay $20 \%$ morc of the overruns. Finally, cven within firms that do some internal work (and are therefore more homogencous), it is the case that firms bear more of the overrun in external contracts than in internal contracts. Therefore it docs not scem to be the casc that the differences in the share of the overrun borne by young firms can be cxplained by systematic differences in competence betwecn young and old firms.

\footnotetext{
${ }^{5 ;}$ Of coursc the actual contracts do not say anything about dividing the overrun. Thereforc what we arc referring to here is a fully efficient implicit contract.

¿fi Or more generally, firms that we have called so far "low reputation" firms.
} 


\subsubsection{Underbidding by Young Firms}

One could imagine that even in a world where contracts are effectively complete, young firms might systcmatically underbid (quote a price based on intentionally low estimates) to win the project. Of course the client knows this, and in the optimal contract corrects for it by holding them responsible for the extra overrun resulting from the underbidding. ${ }^{57}$ Young firms therefore end up paying for a higher share of the overrun. However it should be easy to sec that the same objections that we list above to the competence-bascd explanation also apply in this casc.

\subsubsection{Varying Level of Moral Hazard}

The arguments against the two previous altcrnatives are based on the assumption that the mistakes (or prediction errors) are deliberate. Once we allow for such moral hazard, the clicnt may well not be willing to insure the firm. Old firms could be less prone to moral hazard than young firms, and therefore bear less risk than young firms. The evidence we have presented on mean and variance of the ovcrrun cannot respond to this kind of criticism, since they are endogenous: young firms could be gencrating the same level of ovcrruns as old firms, preciscly because they face higher punishments. Note however that this would be a real alternative to our vicw only if the levels of moral hazard were common knowledge (i.c., if there was no lcarning about the type of the firm or the client - if there was learning, it would just be a variant of our reputation model). Morcover, it is not clear why, in this alternative scenario, it should makc any difference that a firm is working with a repeated client. The level of moral hazard is unlikely to change very much between the first and the sccond contracts for a specific clicnt. The fact that firms are treated differently the sccond time around must therefore indicate that there is lcarning going on about the charactcristics of the firm.

\subsubsection{Dynamic Moral Hazard}

The fact that repeat contracts are different from first time contracts could perhaps be explained in terms of the cvolution of a dynamic incentive contract, in the absence of any learning. However this would not explain the contrast betwecn the first-time contracts faced by young and old firms. Morcover it is not easy to sec why, in this view, the age effect would be smaller when it is a

\footnotetext{
${ }^{i \pi}$ Again we are referring here to a fully efficient implicit contract.
} 
repcated contract.

\subsubsection{Varying Levels of Honesty}

Young firms could also differ from old firms in their propensity to report costs honestly. They could be more prone to try to report inflated costs, or to pretend that changes duc to their own incompetence are due to the clicnt changing his mind. If the clicnt could not tell the cheaters apart, then the analysis of such a model would be similar to the analysis of the model we propose, and lead to the same conclusion (the reputation of old firms would be a reputation for honesty instcad of a reputation for reliability). As we mentioncd carlicr, our modeling choicc was to model a reputation for reliability, but it is clcar that the analysis could be carricd out with a different reason for the importance of reputation.

Note howcver that if clicnts could tell apart cheaters and honest firms, and punish chcatcrs by imposing them to pay more of the overrun, then we would also observe that young firms would pay on average more of the overrun (but this would not result in any social cost, unlike in our model or a version of the model with a reputation for honesty). Assuming that firms report in the questionnaire what they have reported to the clicnt, then the evidence that young firms pay more often than old firms overruns reportedly causcd by the clicnt would simply reflect the fact that they arc lying more often than old firms. Bccausc this argument rests on the fact that firms arc lying in what thcy report to us as well as in what thcy say to their clicnt, it is not casily verified or invalidated in the data. Note however that this argument implics that the clicnts never make any mistake in telling apart cheaters and honest firms. It is therefore sclf-defcating: why would firms cheat in the first place if they know that they arc going to be found out? Morcover thrce facts arc difficult to rcconcile with this explanation: First, firms pay on average $50 \%$ of the ovcrrun when they report that the client is fully responsible for it. The suggested cxplanation would thereforc imply an implausibly high fraction of cheaters among Indian softwarc companics (young and old).

Morcover, if the clicnt has perfect information and can cnforce any sharing ex post, therc should be no variation in the contractual form, or at least it should not be related to the final outcome. However, firms pay more of the overrun when they have fixed-price contracts than when they have time and matcrial contracts. Furthermore, young firms have morc often fixedprice contracts. Thereforc the ex ante contracts scem both to be relevant and to be used by the 
clients, which is not consistent with the world we just rescribed.

Finally, note that such a model would not explain the difference between contracts with repcated and new clients, or the difference between internal and external contracts: if the client has perfect information, then it is not casy to cxplain why firms would behave differently when dcaling with different types of clicnts.

\section{Conclusion}

We set out in this paper to look for cvidence that reputation plays an important role in determining contractual outcomes. We find that the evidence sccms to strongly support this view, though given that the cvidence is indirect (we do not actually observe people looking at reputation when deciding on contracts) and there are important firm characteristics that are potcntially corrclated with our measures of reputation, some doubts clcarly remain.

The conclusion that reputation matters is of coursc important in itself: it gives support to a range of theorics that arc based on limitations of contracting. Morcover, it might suggest an cxplanation of why the Indian software industry is not much larger (Indian software cxports were only worth $3.4 \%$ of the 1995 worldwide outsourcing business) given its obvious labor-cost advantagc $^{58}$ and the fact that this is a very labor-intensive industry. Or, to state the same point differently, why is it an equilibrium for software professionals in India to get paid so much less than their U.S. countcrparts? Reputation at the firm level is one possible cxplanation: most Indian firms are simply not trusted cnough to be given important contracts. Whilc our cvidence camnot directly substantiate this view, the fact that reputation is important within the Indian industry suggests that it also ought to be important when an Amcrican clicnt is deciding whether to go to a firm in India or to onc in the U.S.

To add support to this vicw, our results also suggest that the process of reputation formation is rather incficient. This is reflected in the fact that after controlling for agc, whether or not a firm is dealing with a repcat buycr still makes a substantial difference to the contract. In other words, repcat buycrs clcarly know much morc about the firm than the market does. In other words, the fact that a firm performed well in the past vis a vis onc firm takes time to bccome

\footnotetext{
${ }^{5 x}$ The U.S. imports a very large number of Indian software professionals for short-tcrm assignments at a cost of more than twice what they would carn in India.
} 
public information. This is of course consistcnt with rational bchavior on the part of the client but it clcarly lurts the firm.

The policy implication of this vicw is that a credible system for rating firms modeled on credit rating systcms may play an important role in the cvolution of industrics such as the software industry where contracting is inlicrently problematic, by making it possible for the market to efficiently aggregatc all that is known about cach firm.

\section{References}

[1] Bajari, Patrick and Steven Tadelis (1999), "Procurement Contracts: Fixcd Price vs. Cost Plus", MIIMEO, Stanford University.

[2] Baker G., R. Gibbons and K. Murphy (1997) "Implicit contracts and the theory of the firm" NBER Working Papcr \#6177.

[3] Barron J. and John Umbeck (1984) "The effect of different contractual arrangements: the case of retail gasoline markct" Journal of Law and Economics 27:313-328.

[4] Crocker K. and K. Reynolds (1993) "The efficiency of incomplete contracts: an cmpirical analysis of air force engine procurcment" RAND Journal of Economics 24-1:127-146.

[5] Genesore D. (1993) "Adverse sclection in the wholcsalc uscd car market" Journal of Political Economy 101-4:644-665.

[6] Grcif A. (1994) "Cultural bclicfs and the organization of socicty: A historical and thcorctical rcflcction on collectivist and individualist socictics" Journal of Political Economy 102-5:912950.

[7] Hccks R. (1996) India's Software Industry. State Policy, Liberalisation and Industrial Development, Sagc Publication, Ncw Dclhi, Thousand Oaks, London.

[8] Holmstrom, Bengt (1982) "Moral Hazard in Tcams" Bell Journal of Economics 13-2:324-40.

[9] Johnson, S., J. McMillan and C. Woodruff, (1999) "Contract Enforcement in Transition", MINEO, MIT. 
[10] Joskow, P., (1987) "Contract duration and relationship specific investment: cmpirical cvidence from coal markets" American Economic Review 77-1:168-185.

[11] Kandori, M. (1992) "Social norms and community cnforcenent" Review of Economics Studies 59:63-80.

[12] Lafontainc F. and K. Shaw (1996) "The dynamics of franchisc contracting: evidence from pancl data" NBER Working Papcr \#5585.

[13] Masten S. and K. Crocker (1985) "Efficient adaptation in long-term contracts: Takc-or-pay provisions for natural gas" American Economic Review 75-5:1083-1093.

[14] Monteverde K. and D.J. Tecce (1982) "Supplicr switching costs and vertical integration in the automobile industry" Bell Journal of Economics 13:206-213.

[15] NASSCONI (1997) Indian Software Directory, CD-ROM.

[16] Pittman R. (1991) "Specific investment, contracts and opportunism: the cvolution of railroad sidetrack agrecments" Journal of Law and Economics 34:565-589.

[17] Prcssman, Roger S.(1997) Software Engineering, A Practitioner's Approach, 4d cdition, MacGraw Hill International cditions, Software Enginecring Serics.

[18] Rauch, James and Jocl Watson, "Starting Small in an Unfamiliar Environment", MIMEO, University Of California at San Dicgo.

[19] Shcpard, A. (1993) "Contractual form, retail gasoline, and assct characteristic in gasoline r'ctailing" RAND Journal of Economics 24-1:58-77.

[20] STPI (1997) Software Technology Parks of India, MIMEO, Bangalorc.

[21] Tirole, Jean (1996) "A Theory of Collective Reputations (with Applications to the Persistcnce of Corruption and to Firm Quality)" Review of Economic Studies 63.1:1-22. 
Figure 1

Proportion of fixed cost contracts

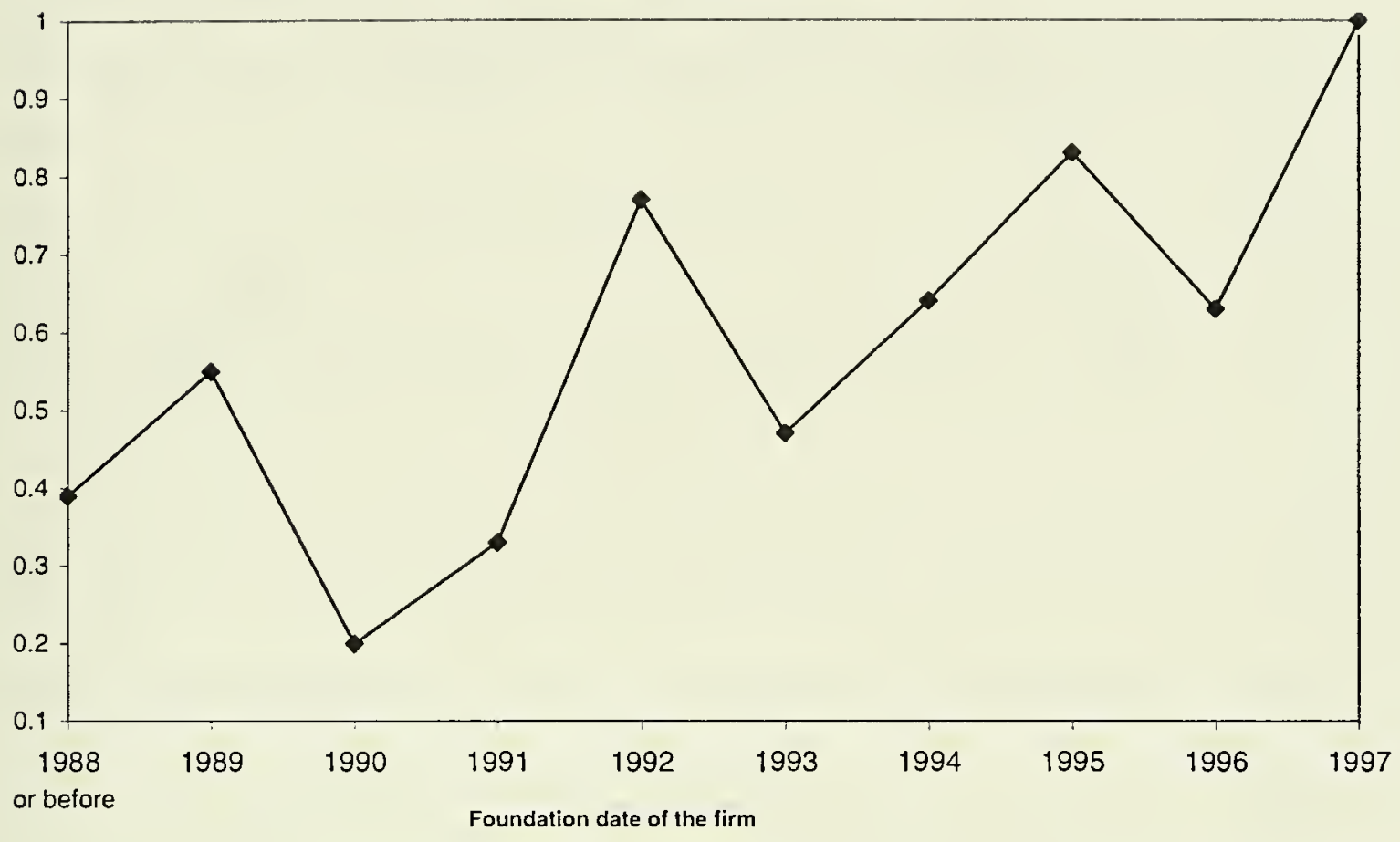

Figure 2

Share of overrun paid for by the firm

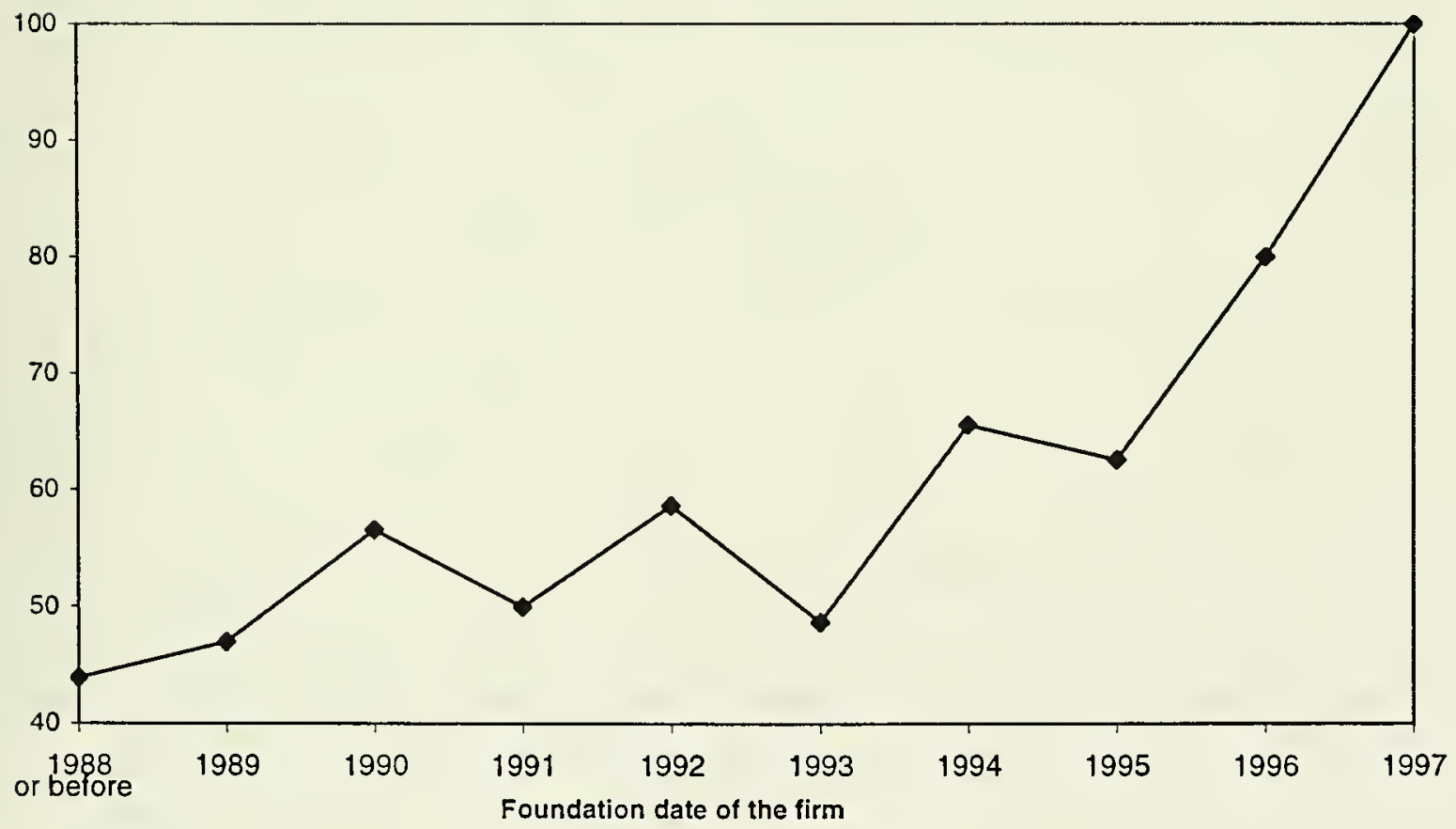


Figure 3:

Mean of project overrun

(percentage of initial evaluation)

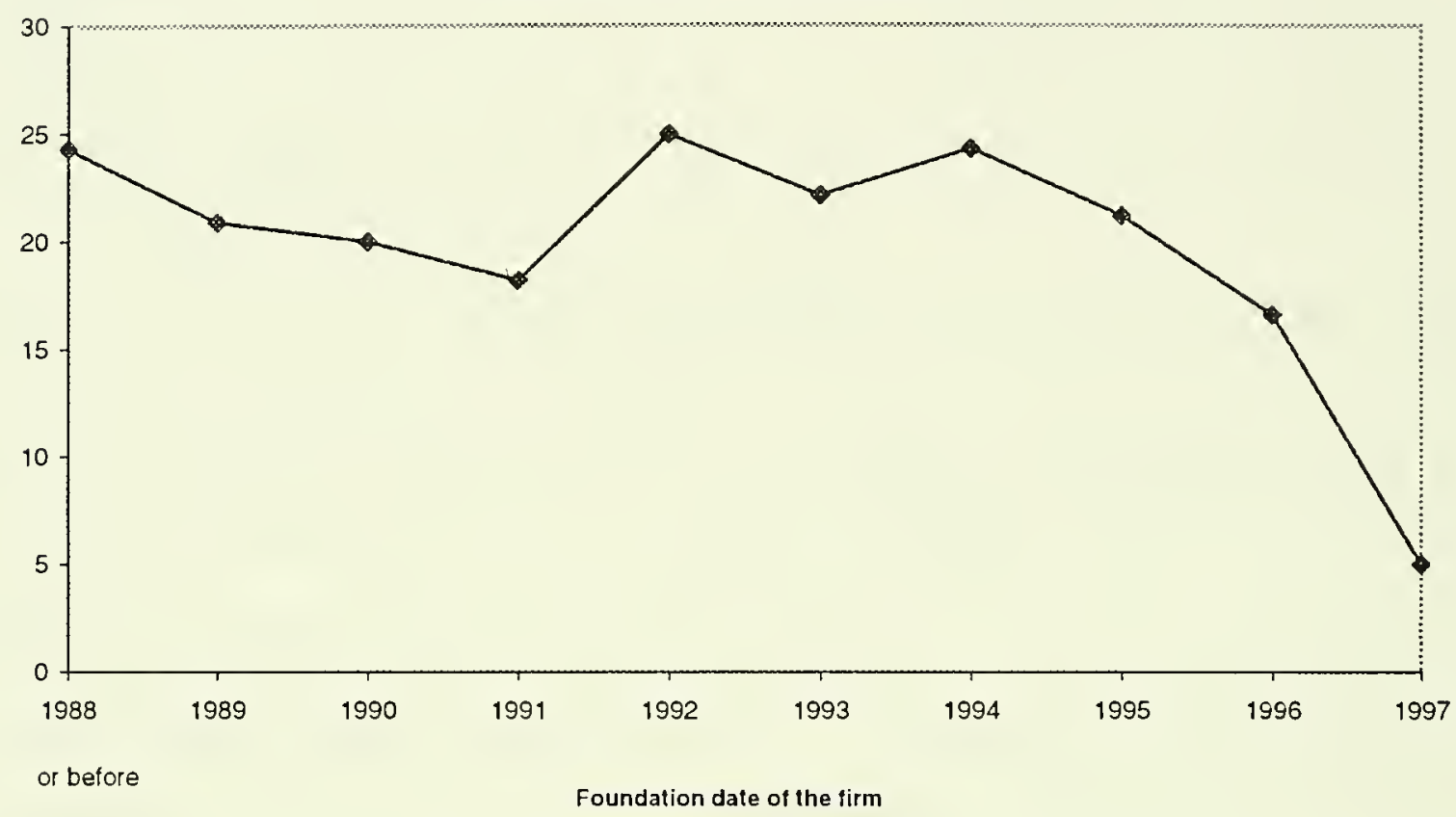

Figure 4

Average Firm Turnover in 1997/98 (Millions \$US)

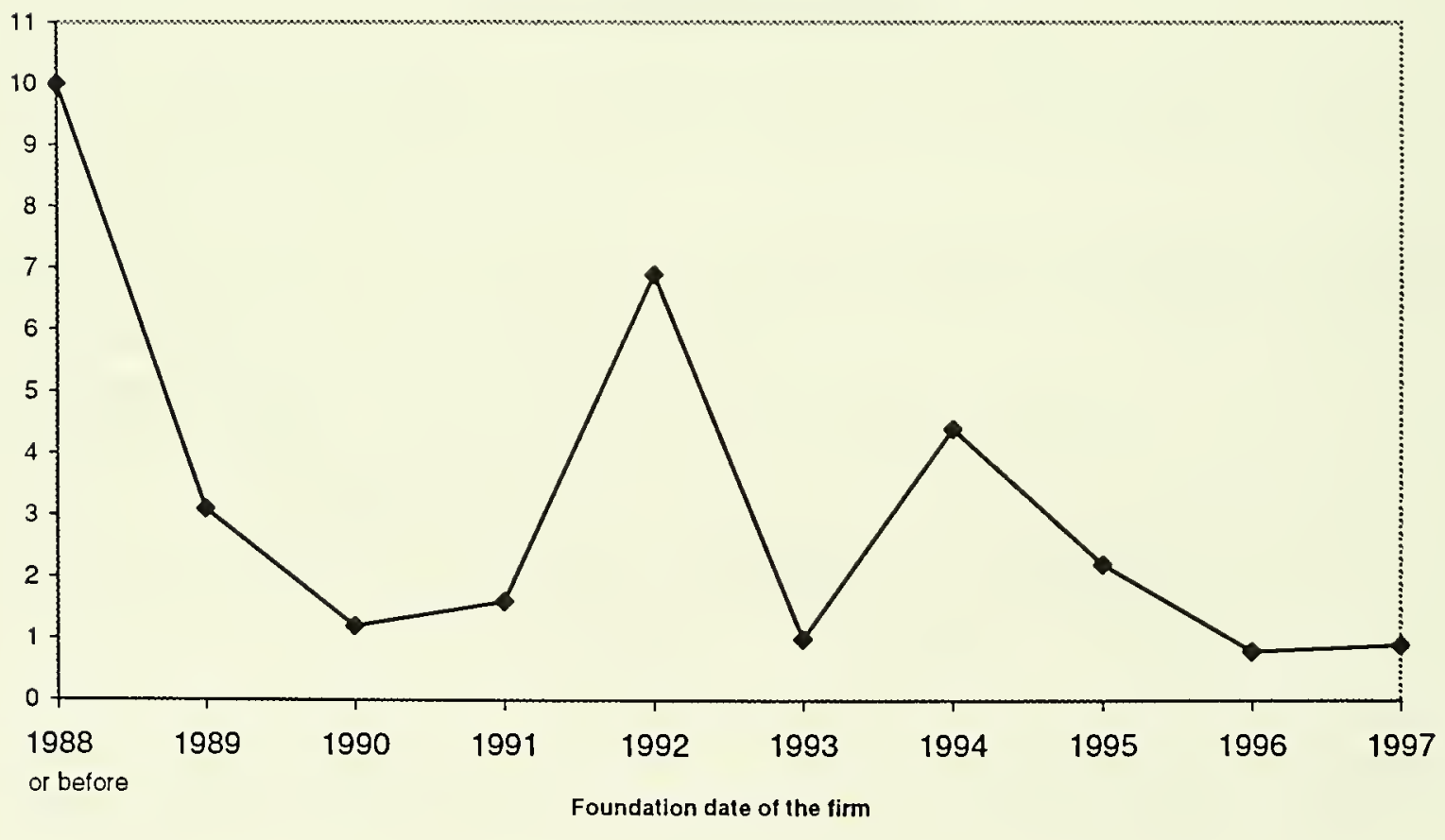


Figure 5:

Subjective complexity measure

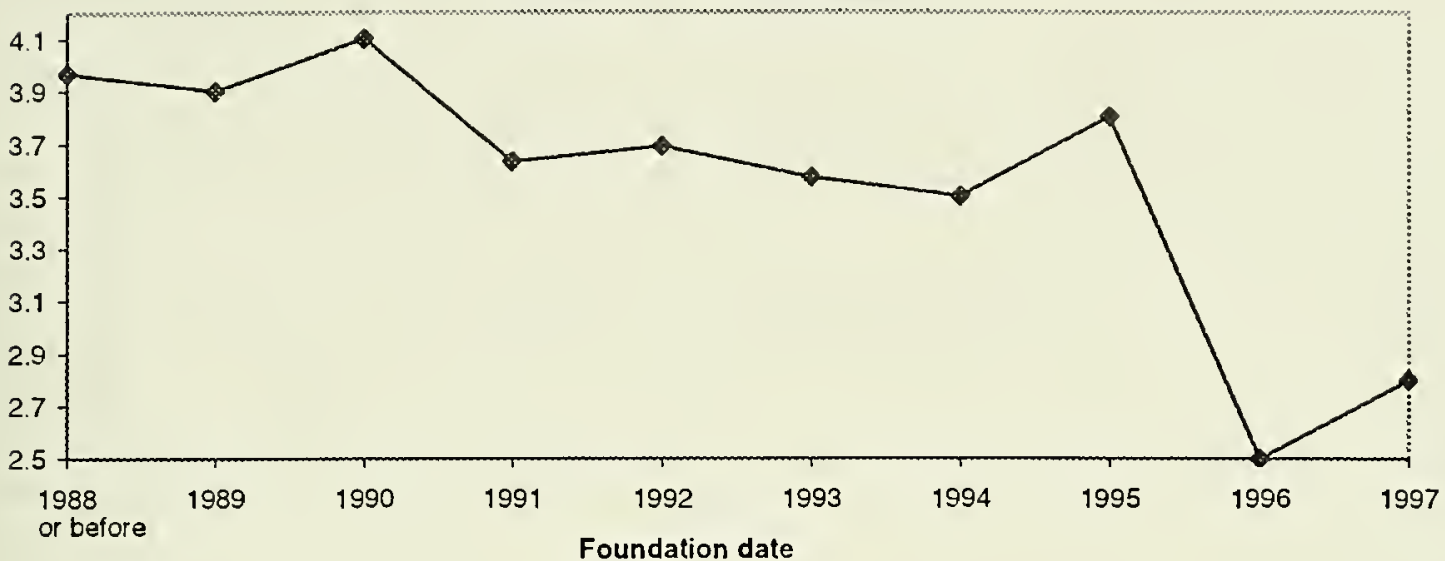

Figure 6:

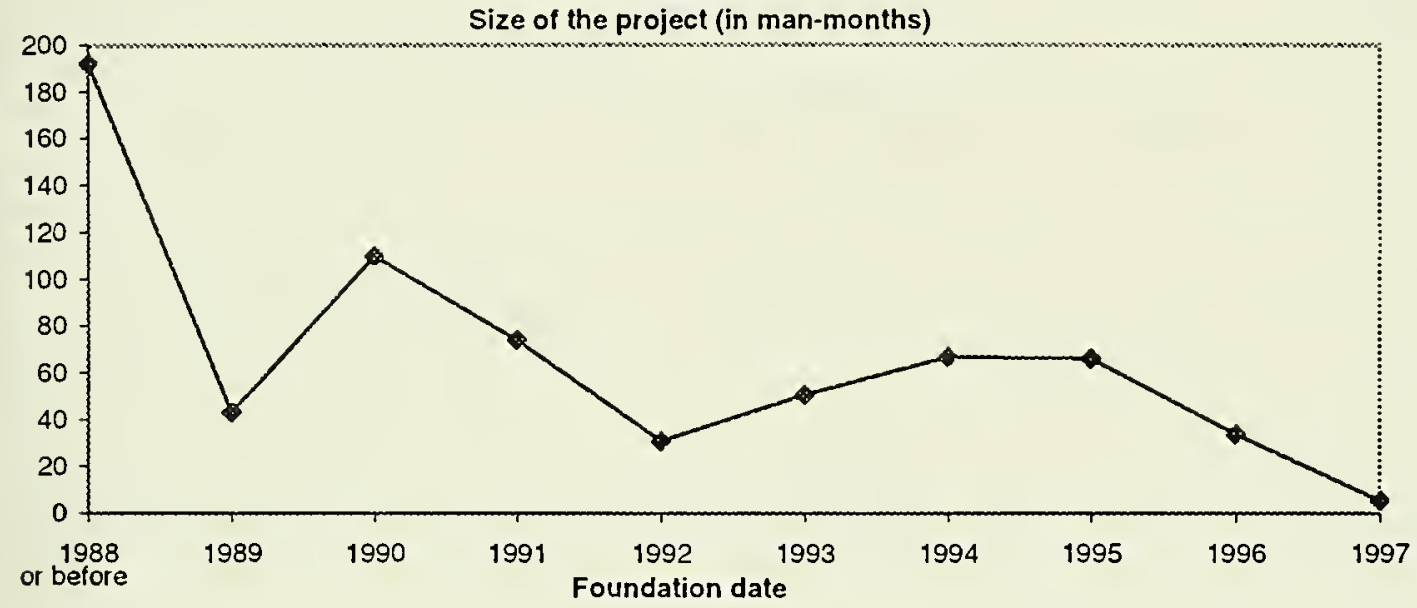

Figure 7:

Proportion of "simple" project

(cad, $y 2 k$, web pages, data manipulation)

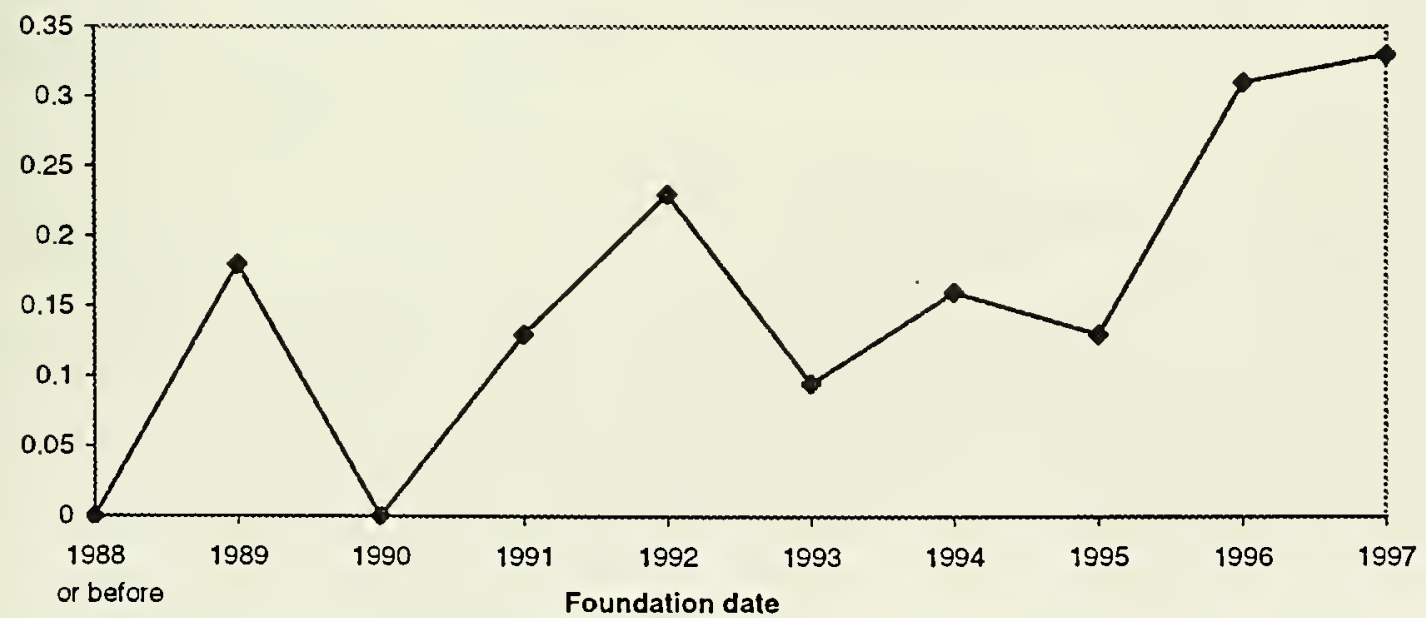


Figure 8: Cumulative distribution of overrun

A: Young firms

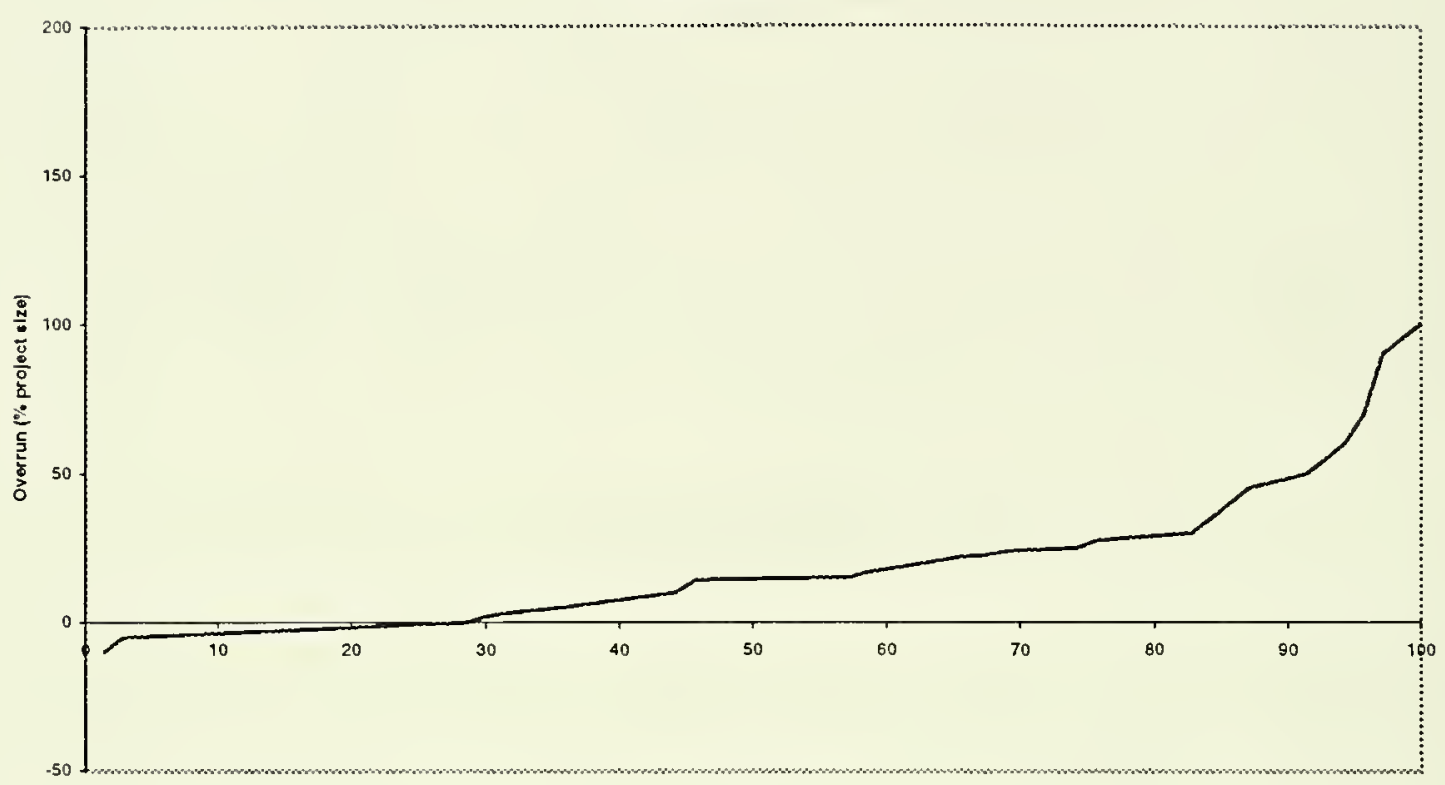

$\%$ or trme

B: Old firms

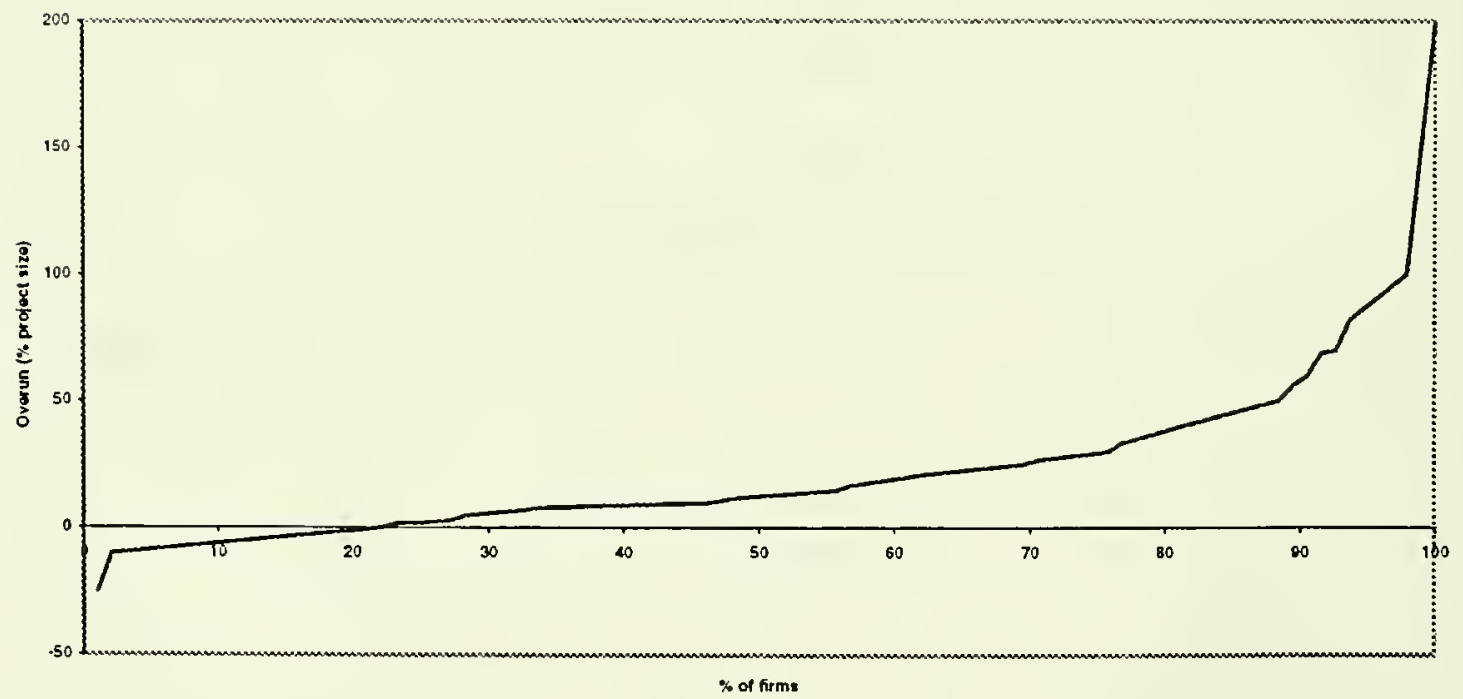




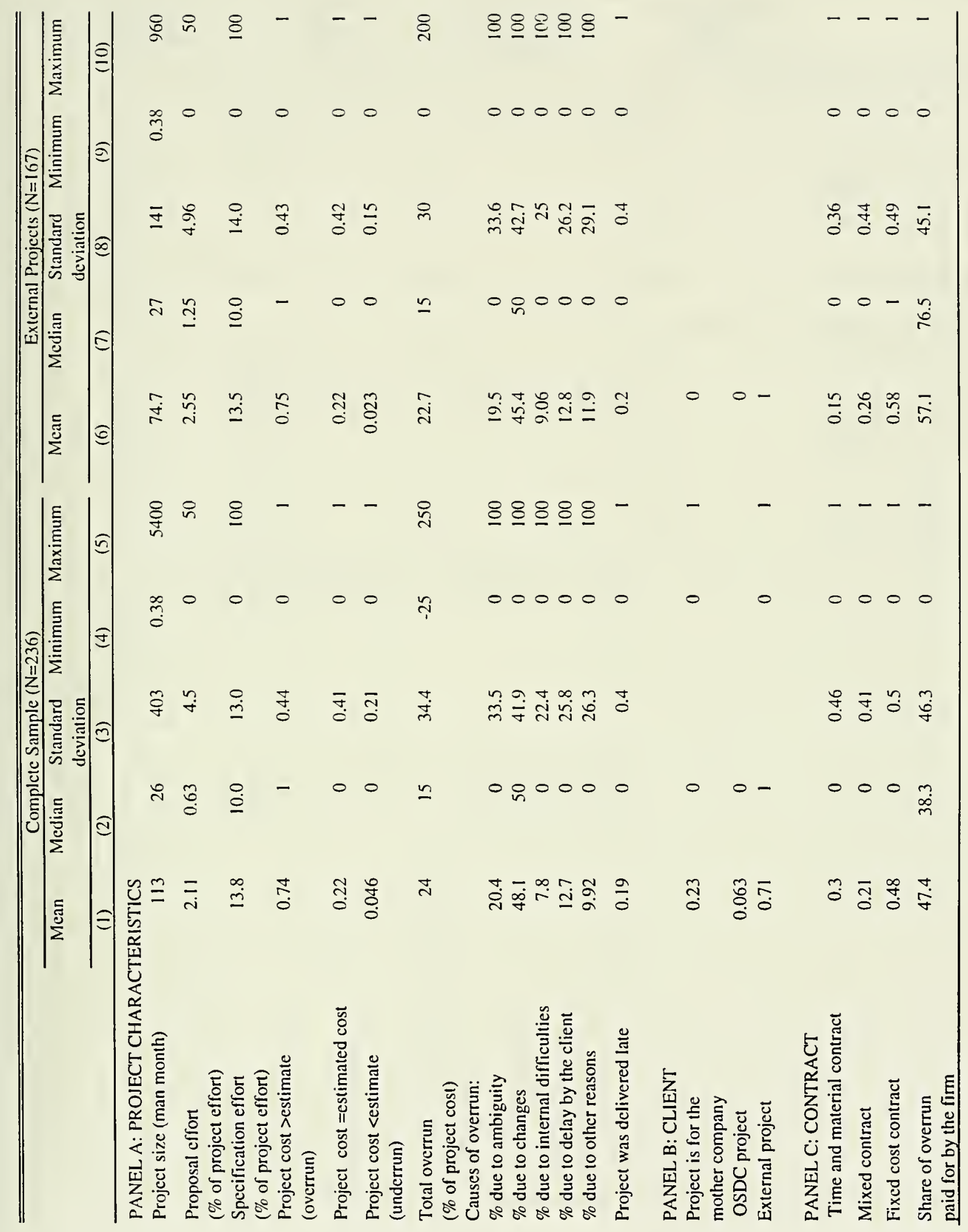


Share of overrun for paid by the firm as a function of initial contract

\begin{tabular}{|c|c|c|c|c|}
\hline & $\begin{array}{c}\text { Proportion paying } \\
100 \% \\
\end{array}$ & $\begin{array}{l}\text { Proportion paying } \\
\text { betwecn } 0 \text { and } 100 \%\end{array}$ & $\begin{array}{c}\text { Proportion paying } \\
0 \% \\
\end{array}$ & $\begin{array}{l}\text { Avcrage share of the overrun } \\
\text { paid for by the firm }\end{array}$ \\
\hline \multicolumn{5}{|c|}{ PANEL A: ALL CONTRACTS } \\
\hline All contracts & 39.29 & 17.85 & 42.86 & $\begin{array}{r}47.4 \\
(3.58)\end{array}$ \\
\hline $\begin{array}{l}\text { Time and material } \\
\text { contracts }\end{array}$ & 11.1 & 11.12 & 77.78 & $\begin{array}{r}15.6 \\
(4.92)\end{array}$ \\
\hline Mixed contracts & 34.29 & 25.71 & 40 & $\begin{array}{r}51.6 \\
(7.69)\end{array}$ \\
\hline Fixed cost contracts & 54.12 & 18.82 & 27.06 & $\begin{array}{r}63.1 \\
(4.83)\end{array}$ \\
\hline \multicolumn{5}{|c|}{ PANEL B: EXTERNAL CONTRACTS } \\
\hline All contracts & 47.58 & 20.97 & 31.45 & $\begin{array}{r}57.1 \\
(4.06)\end{array}$ \\
\hline $\begin{array}{r}\text { Time and material } \\
\text { contracts }\end{array}$ & 17.65 & 23.53 & 58.82 & $\begin{array}{r}28.2 \\
(9.56)\end{array}$ \\
\hline Mixed contracts & 40.62 & 25 & 34.38 & $\begin{array}{r}50.9 \\
(8.08)\end{array}$ \\
\hline Fixed cost contracts & 56.76 & 18.92 & 24.32 & $\begin{array}{r}65.8 \\
(5.07) \\
\end{array}$ \\
\hline
\end{tabular}




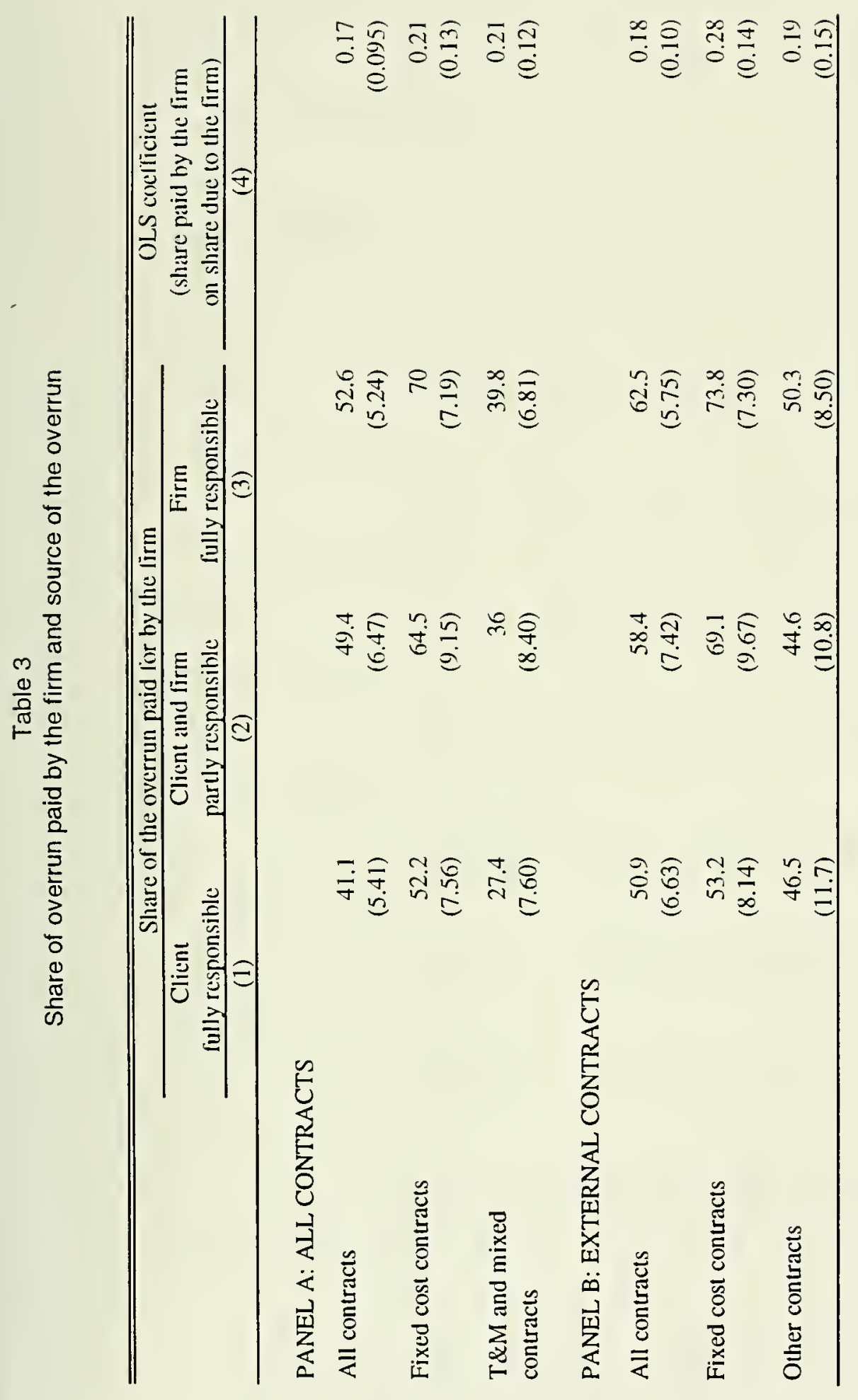




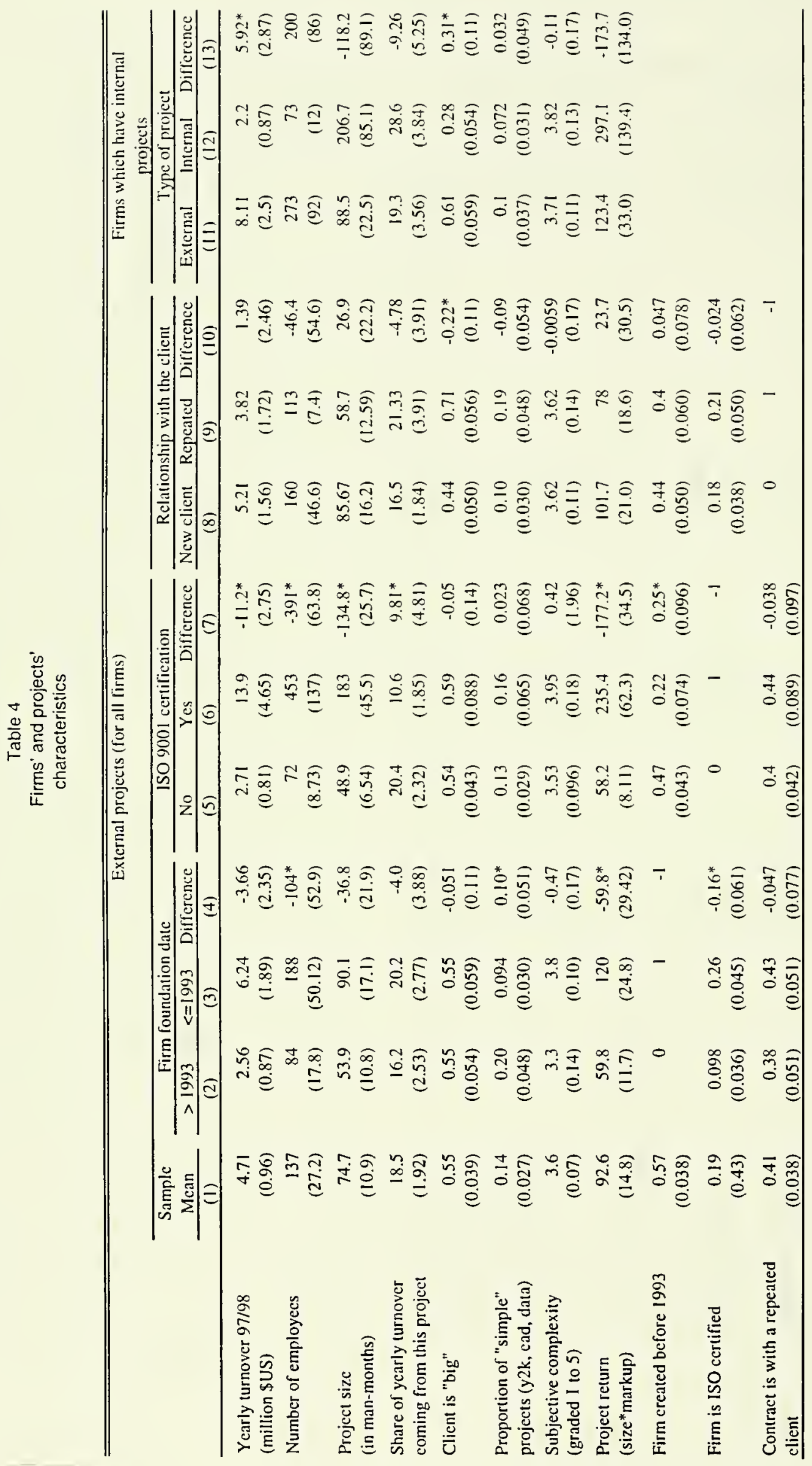




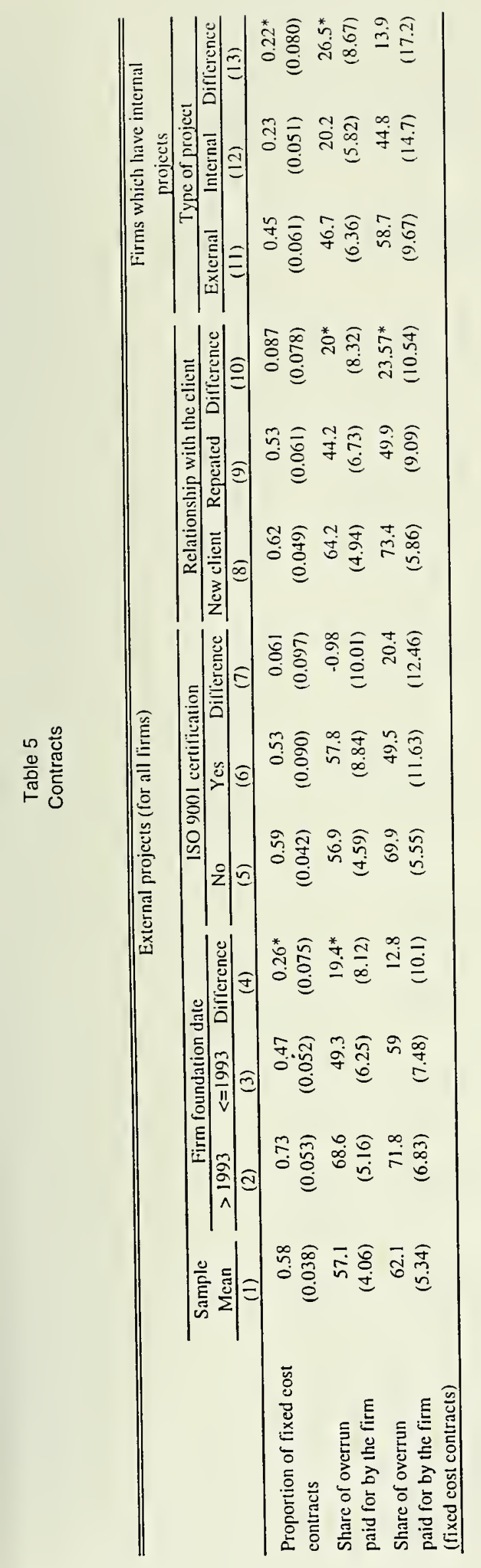




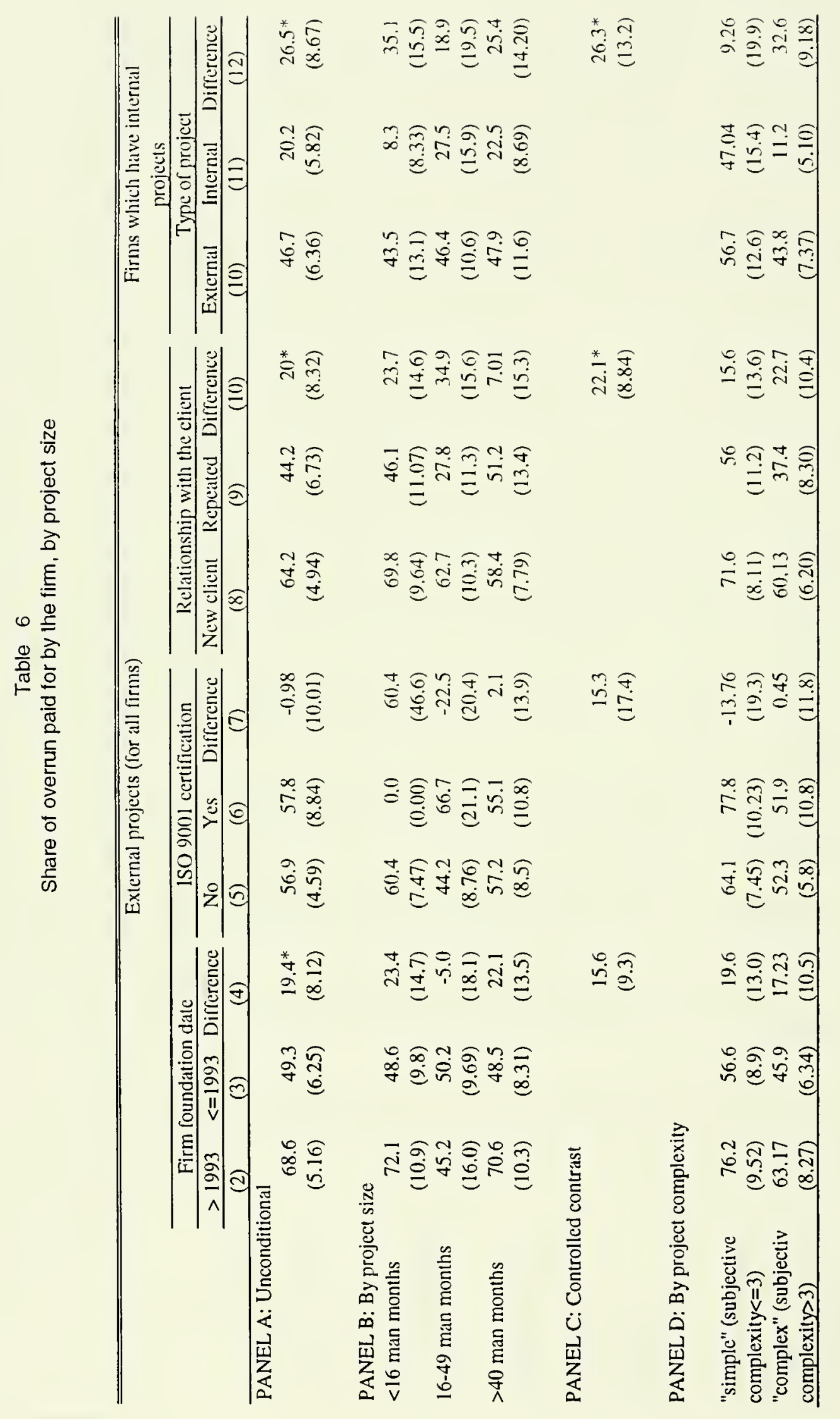




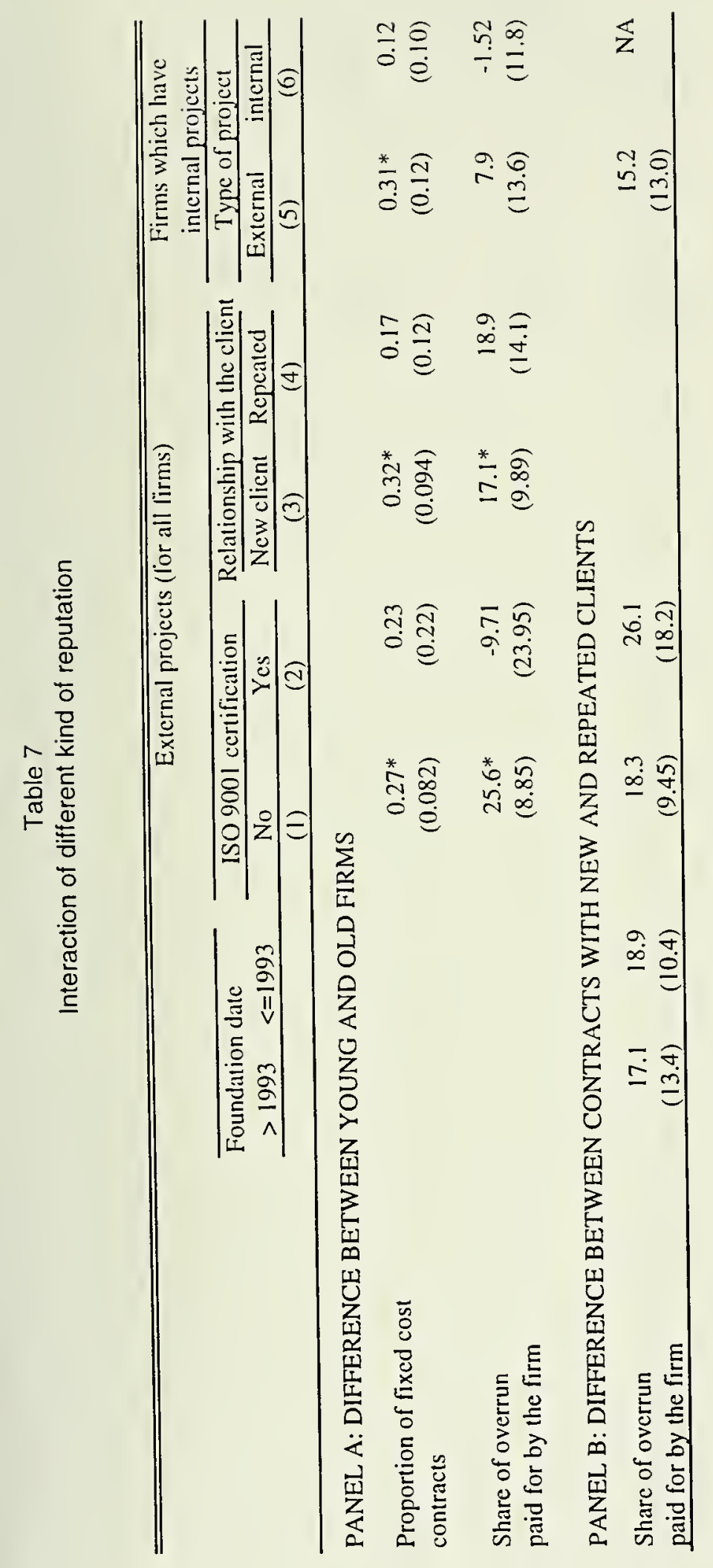




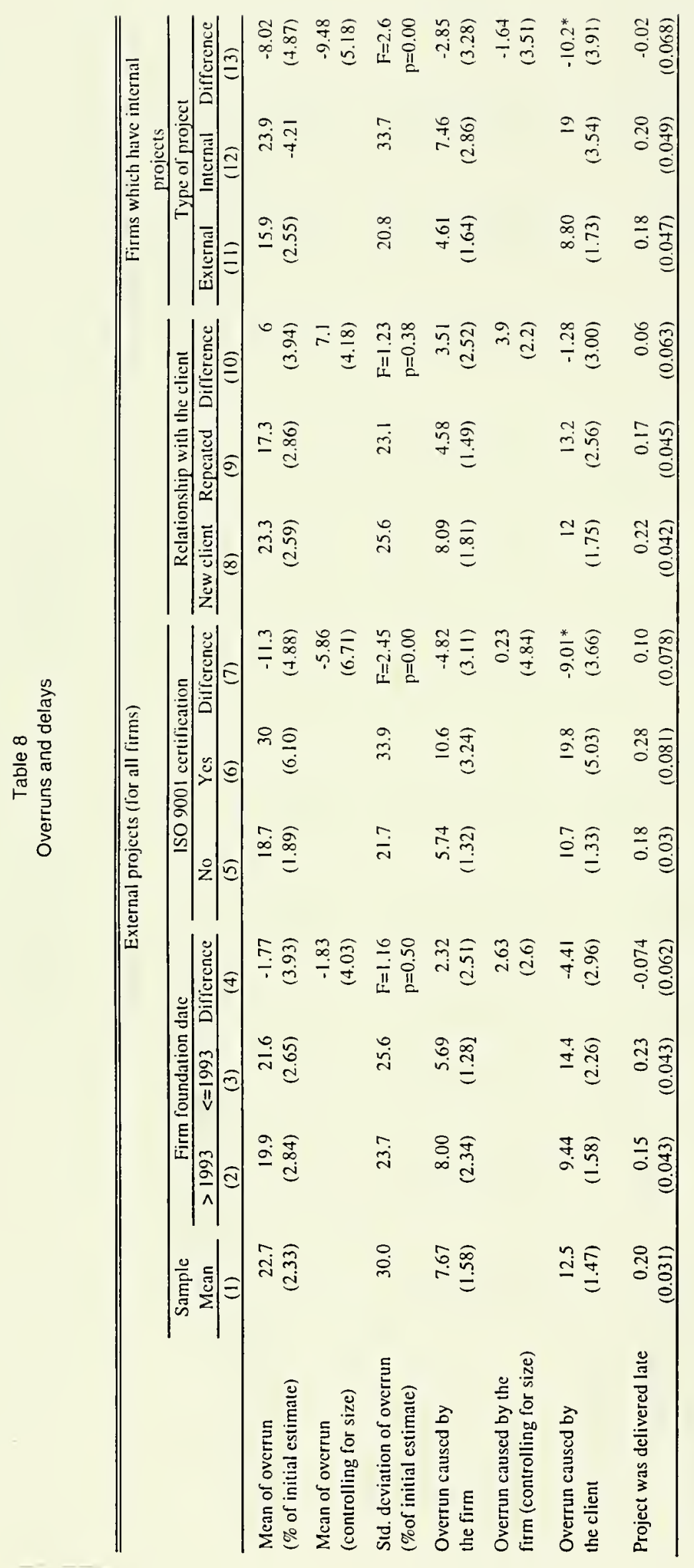


Table 9

Share of overrun paid

by the firm, by project and

client size

\begin{tabular}{|c|c|c|c|c|c|c|}
\hline & \multirow{2}{*}{\multicolumn{3}{|c|}{$\begin{array}{c}\text { Young firms } \\
\text { Size of project }\end{array}$}} & \multirow{2}{*}{\multicolumn{3}{|c|}{$\frac{\text { Old firms }}{\text { Size of project }}$}} \\
\hline & & & & & & \\
\hline & All & $<$ median & $>$ median & All & $<$ median & $>$ median \\
\hline & (1) & (2) & (3) & (4) & (5) & (6) \\
\hline All clients & $\begin{array}{r}68.7 \\
(5.15)\end{array}$ & $\begin{array}{r}72.5 \\
(8.17)\end{array}$ & $\begin{array}{r}63.3 \\
(9.82)\end{array}$ & $\begin{array}{r}46.6 \\
(6.25)\end{array}$ & $\begin{array}{r}54.7 \\
(8.34)\end{array}$ & $\begin{array}{r}45.7 \\
(6.60)\end{array}$ \\
\hline $\begin{array}{l}\text { Small or medium } \\
\text { clients }\end{array}$ & $\begin{array}{r}77.5 \\
(7.93)\end{array}$ & $\begin{array}{r}79.9 \\
(10.0)\end{array}$ & $\begin{array}{r}73.2 \\
(13.7)\end{array}$ & $\begin{array}{r}65.4 \\
(7.5)\end{array}$ & $\begin{array}{r}61.1 \\
(12.7)\end{array}$ & $\begin{array}{l}68.2 \\
(9.5)\end{array}$ \\
\hline Big clients & $\begin{array}{r}59.8 \\
(9.49)\end{array}$ & $\begin{array}{r}63.5 \\
(13.5)\end{array}$ & $\begin{array}{r}55.8 \\
(13.9)\end{array}$ & $\begin{array}{r}37.6 \\
(6.56)\end{array}$ & $\begin{array}{r}50.2 \\
(11.2)\end{array}$ & $\begin{array}{r}29.3 \\
(7.72)\end{array}$ \\
\hline
\end{tabular}







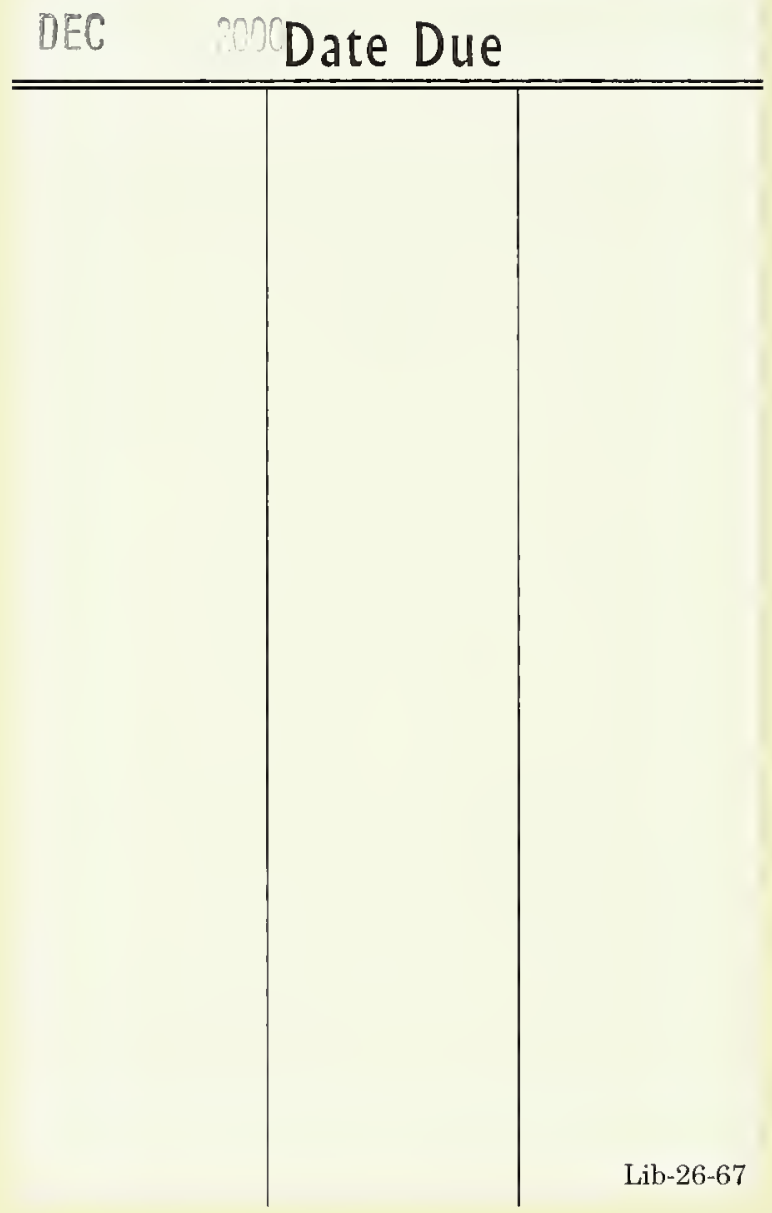




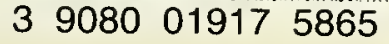


